\title{
An analysis of fast photochemistry over high northern latitudes during spring and summer using in-situ observations from ARCTAS and TOPSE
}

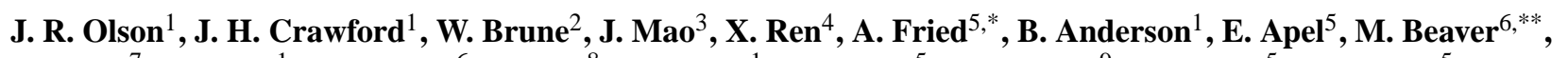
D. Blake $^{7}$, G. Chen ${ }^{1}$, J. Crounse ${ }^{6}$, J. Dibb ${ }^{8}$, G. Diskin ${ }^{1}$, S. R. Hall ${ }^{5}$, L. G. Huey ${ }^{9}$, D. Knapp ${ }^{5}$, D. Richter ${ }^{5}$, D. Riemer ${ }^{10}$, J. St. Clair ${ }^{6}$, K. Ullmann ${ }^{5}$, J. Walega ${ }^{5}$, P. Weibring ${ }^{5}$, A. Weinheimer ${ }^{5}$, P. Wennberg ${ }^{6}$, and A. Wisthaler ${ }^{11^{* * * *}}$

${ }^{1}$ NASA Langley Research Center, Hampton, VA, USA

${ }^{2}$ Department of Meteorology, Penn State, University Park, PA, USA

${ }^{3}$ Atmospheric and Oceanic Sciences, Department of Geosciences, Princeton University, Princeton, NJ, USA

${ }^{4}$ NOAA Air Resources Laboratory, Silver Spring, MD, USA

${ }^{5} \mathrm{NCAR}$, Boulder, CO, USA

${ }^{6}$ California Institute of Technology, Pasadena, CA, USA

${ }^{7}$ School of Physical Sciences, Department of Chemistry, University of California, Irvine, CA, USA

${ }^{8}$ School of Physical Sciences, Department of Chemistry, University of New Hampshire, Durham, NH, USA

${ }^{9}$ Georgia Institute of Technology, Atlanta, GA, USA

${ }^{10}$ Rosenstiel School of Marine and Atmospheric Science, University of Miami, Miami, FL, USA

${ }^{11}$ Institute for Ion Physics and Applied Physics, University of Innsbruck, Innsbruck, Austria

*now at: Institute of Arctic and Alpine Research, University of Colorado, Boulder, CO, USA

** now at: Environmental Protection Agency, Research Triangle Park, NC, USA

*** now at: Norwegian Institute of Air Research, Kjeller, Norway

Correspondence to: J. R. Olson (jennifer.r.olson@nasa.gov)

Received: 12 March 2012 - Published in Atmos. Chem. Phys. Discuss.: 11 April 2012

Revised: 9 July 2012 - Accepted: 10 July 2012 - Published: 1 August 2012

\begin{abstract}
Observations of chemical constituents and meteorological quantities obtained during the two Arctic phases of the airborne campaign ARCTAS (Arctic Research of the Composition of the Troposphere from Aircraft and Satellites) are analyzed using an observationally constrained steady state box model. Measurements of $\mathrm{OH}$ and $\mathrm{HO}_{2}$ from the Penn State ATHOS instrument are compared to model predictions. Forty percent of $\mathrm{OH}$ measurements below $2 \mathrm{~km}$ are at the limit of detection during the spring phase (ARCTASA). While the median observed-to-calculated ratio is near one, both the scatter of observations and the model uncertainty for $\mathrm{OH}$ are at the magnitude of ambient values. During the summer phase (ARCTAS-B), model predictions of $\mathrm{OH}$ are biased low relative to observations and demonstrate a high sensitivity to the level of uncertainty in $\mathrm{NO}$ observations. Predictions of $\mathrm{HO}_{2}$ using observed $\mathrm{CH}_{2} \mathrm{O}$ and $\mathrm{H}_{2} \mathrm{O}_{2}$
\end{abstract}

as model constraints are up to a factor of two larger than observed. A temperature-dependent terminal loss rate of $\mathrm{HO}_{2}$ to aerosol recently proposed in the literature is shown to be insufficient to reconcile these differences. A comparison of ARCTAS-A to the high latitude springtime portion of the 2000 TOPSE campaign (Tropospheric Ozone Production about the Spring Equinox) shows similar meteorological and chemical environments with the exception of peroxides; observations of $\mathrm{H}_{2} \mathrm{O}_{2}$ during ARCTAS-A were 2.5 to 3 times larger than those during TOPSE. The cause of this difference in peroxides remains unresolved and has important implications for the Arctic $\mathrm{HO}_{\mathrm{x}}$ budget. Unconstrained model predictions for both phases indicate photochemistry alone is unable to simultaneously sustain observed levels of $\mathrm{CH}_{2} \mathrm{O}$ and $\mathrm{H}_{2} \mathrm{O}_{2}$; however when the model is constrained with observed $\mathrm{CH}_{2} \mathrm{O}, \mathrm{H}_{2} \mathrm{O}_{2}$ predictions from a range of 
rainout parameterizations bracket its observations. A mechanism suitable to explain observed concentrations of $\mathrm{CH}_{2} \mathrm{O}$ is uncertain. Free tropospheric observations of acetaldehyde $\left(\mathrm{CH}_{3} \mathrm{CHO}\right)$ are 2-3 times larger than its predictions, though constraint of the model to those observations is sufficient to account for less than half of the deficit in predicted $\mathrm{CH}_{2} \mathrm{O}$. The box model calculates gross $\mathrm{O}_{3}$ formation during spring to maximize from $1-4 \mathrm{~km}$ at $0.8 \mathrm{ppbv} \mathrm{d}^{-1}$, in agreement with estimates from TOPSE, and a gross production of 2$4 \mathrm{ppbv} \mathrm{d}^{-1}$ in the boundary layer and upper troposphere during summer. Use of the lower observed levels of $\mathrm{HO}_{2}$ in place of model predictions decreases the gross production by $25-50 \%$. Net $\mathrm{O}_{3}$ production is near zero throughout the ARCTAS-A troposphere, and is $1-2$ ppbv in the boundary layer and upper altitudes during ARCTAS-B.

\section{Introduction}

The climate of the Arctic environment is changing more rapidly than any other region. While polar temperature trends vary, the overall trend is one of substantial warming (Arctic Climate Impact Assessment http://amap.no/acia/), and the September sea ice extent is decreasing at accelerating rates (Lemke et al., 2007; Comiso et al., 2008). Studies indicate that regional radiative forcing from aerosols and tropospheric $\mathrm{O}_{3}$ is likely to be a significant contributor to the Arctic warming trend during the winter and spring, and that factors controlling these constituents in the Arctic are poorly understood and simulated (Stohl, 2006; Law and Stohl, 2007; Shindell et al., 2007; Quinn et al., 2008).

A major mechanism for long-range transport of $\mathrm{O}_{3}$, aerosols and other pollutants into high latitudes is the nearsurface transport of pollution from northern Euro-Asian sources into the wintertime Arctic (the "Arctic haze" phenomenon; e.g., Radke et al., 1984; Brock et al., 1989; Shaw, 1995). Recent studies have expanded upon that understanding to show that transport of middle latitude pollutants into the Arctic can occur throughout the extent of the Arctic troposphere at various times throughout the year, from source regions located in Asia, Europe and North America (Stohl, 2006; Shindell et al., 2008; Singh et al., 2010; Fisher et al., 2010). Additionally, emissions from high latitude boreal forest fires over North America and Asia are transported into the Arctic predominantly during summer, but evidence of long range transport from fires is found during spring as well (Scheuer et al., 2003; Singh et al., 2010).

$\mathrm{O}_{3}$ photochemistry at high latitudes is impacted by several unique characteristics: extreme cold and dry conditions and long seasonal periods of darkness followed by long periods of sunlight at high solar zenith angles. The persistent snow and sea ice surface increases incident radiation due to a heightened surface albedo, and photochemical reactions within the snowpack itself result in emissions of gases such as hydrogen peroxide $\left(\mathrm{H}_{2} \mathrm{O}_{2}\right)$, formaldehyde $\left(\mathrm{CH}_{2} \mathrm{O}\right)$, and $\mathrm{HONO}$, which can impact near-surface $\mathrm{HO}_{\mathrm{x}}$ chemistry (Chen et al., 2004; Frey et al., 2009). During spring, enhanced concentrations of gaseous bromine radicals $(\mathrm{BrO})$ are frequently observed over Arctic sea ice upon polar sunrise. The catalytic cycling of these halogen radicals has been implicated as the cause of local scale near-complete destruction of surface $\mathrm{O}_{3}$ and further, they influence the cycling and photochemistry of $\mathrm{HO}_{\mathrm{x}}, \mathrm{NO}_{\mathrm{x}}$, and $\mathrm{O}_{3}$. (e.g., Barrie et al., 1988; Evans et al., 2003; McElroy et al., 1999; von Glasgow et al., 2004). Studies stemming from the 2000 TOPSE aircraft campaign (Tropospheric Ozone Production about the Spring Equinox) highlight the importance of photochemistry at high latitudes, suggesting that gross photochemical $\mathrm{O}_{3}$ formation is equal to or greater than the source from long range transport throughout the spring in the free troposphere, and is greater than transport sources at surface altitudes after March (Stroud et al., 2004; Emmons et al., 2003).

This study examines fast photochemistry from the perspective of in-situ data and model analysis during the high latitude spring and summer, including radical budgets and cycling, and $\mathrm{O}_{3}$ production and destruction. The data are from NASA's 2008 ARCTAS (Arctic Research of the Composition of the Troposphere from Aircraft and Satellites) campaign, and data from springtime high latitudes from portions of the TOPSE campaign are compared to ARCTAS.

\section{Data and modeling approach}

\subsection{Campaign deployments}

\subsubsection{ARCTAS}

The high-latitude portion of ARCTAS was comprised of two deployment phases during spring and summer of 2008 and utilized three aircraft: the NASA DC-8, P-3B and B-200. The DC- 8 instrumentation provided a suite of measurements of species related to aerosol and tropospheric $\mathrm{O}_{3}$ chemistry, pollution sources, and radical chemistry. A more complete description of the aircraft payload is in Jacob et al. (2010).

The spring deployment phase (ARCTAS-A) was based out of Fairbanks, Alaska $\left(65^{\circ} \mathrm{N}, 148^{\circ} \mathrm{W}\right)$ from 1-19 April, during which the DC- 8 flew 9 sorties across the Arctic between Alaska, Thule Greenland, and Iqaluit Canada (see Fig. 1 for DC-8 flight paths during ARCTAS). The summer phase (ARCTAS-B) was based out of Cold Lake, Edmonton Canada $\left(54^{\circ} \mathrm{N}, 110^{\circ} \mathrm{W}\right)$ from 26 June-14 July, with 9 sorties ranging across Canada and up to Thule and Summit in Greenland. A third phase (ARCTAS-CARB) took place immediately prior to ARCTAS-B in coordination with the California Air Resources Board (CARB), and was focused on middle latitude pollution off the coast of California to improve state emission inventories for greenhouse gases and 
Flightpaths for ARCTAS-A,-B and TOPSE

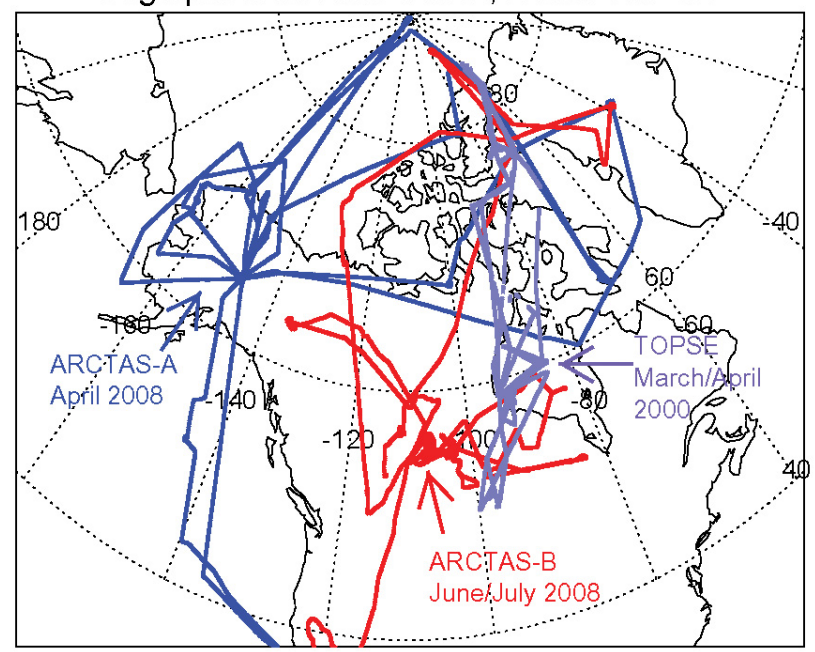

Fig. 1. Flight paths for the NASA DC-8 during ARCTAS-A and -B, and for the NCAR C-130 during TOPSE-sp (subset of TOPSE data obtained during March and April and north of $50^{\circ} \mathrm{N}$ ).

aerosols. The weight of analysis for this high latitude study is on ARCTAS-A and -B.

\subsubsection{TOPSE}

During 2000, NCAR (National Center for Atmospheric Research) sponsored the airborne experiment TOPSE (Tropospheric Ozone Production about the Spring Equinox); it was conducted using an instrumented C-130 aircraft from February-May 2000, which brackets the seasonal period covered by ARCTAS-A. The geographical extent of the campaign included middle and high latitudes over North America $\left(40-85^{\circ} \mathrm{N}\right)$ (Atlas et al., 2003). The high latitude data covered a relatively narrow longitude range over central to eastern Canada and up to Thule, Greenland, meaning most data was obtained further to the east over the North American high latitudes and nearly a decade earlier than during ARCTAS-A (see Fig. 1). Nevertheless, it is reasonable to compare data obtained within the high latitude air masses during these two campaigns. Here, the subset of the TOPSE data obtained during March and April at latitudes north of $50^{\circ} \mathrm{N}$ is considered (herein called TOPSE-sp).

\subsection{Box model}

The NASA Langley Research Center photochemical box model (LaRC-V08) (Crawford et al., 1999; Olson et al., 2006) uses a diurnal steady state (DSS) approach with longlived species constrained to measurements. In the DSS approach, each input point of in-situ data (generally taken from data merges averaged to a 1-min common timeline) is integrated by the model to find an internally self-consistent diurnal cycle for all computed species to within a given toler- ance $(<1 \%)$. Predictions are then taken from the computed diurnal cycle at the same time of day as the data for direct comparison of radical predictions and measurements. Reactions and rates for basic $\mathrm{HO}_{\mathrm{x}}-\mathrm{NO}_{\mathrm{x}}-\mathrm{CH}_{4}-\mathrm{CO}$ chemistry are those recommended by Sander et al. (2006) and Atkinson et al. (2006). Non-methane hydrocarbon (NMHC) chemistry is originally based on the lumped scheme from Lurmann et al. (1986), with adjustments as discussed in the appendix of Crawford et al. (1999). Because halogen chemistry is expected to impact surface $\mathrm{O}_{3}$ chemistry and radical cycling near the surface and in the lower troposphere the box model is updated to include bromine photochemistry (see Table 1).

As in previous studies, photolysis rate coefficients are based on in-situ measurements (Shetter and Muller, 1999). A DISORT four-stream implementation of the NCAR Tropospheric Ultraviolet Visible (TUV) radiative transfer code is first used to calculate the diurnal variation of photolysis rates for clear-sky conditions (Madronich and Flocke, 1998). To adjust these clear-sky rates to account for local cloudiness and surface reflectance, a normalization factor is applied so that observed rates at the time of observation are matched. In the event that a given radical precursor is not constrained to observations, surface deposition and rainout for soluble species are parameterized as in Logan et al. (1981), i.e., for altitudes $<1 \mathrm{~km}$, a surface deposition loss rate of $1 \times 10^{-5} \mathrm{~s}^{-1}$ is assigned to most species impacted by surface deposition, with a smaller loss rate of $0.3 \times 10^{-5} \mathrm{~s}^{-1}$ for $\mathrm{CH}_{3} \mathrm{OOH}$. Above the boundary layer, the rainout parameterization assumes a 5 day lifetime for altitudes up to $4 \mathrm{~km}$, with an exponentially decreasing loss rate above. Aerosol and cloud uptake for $\mathrm{HO}_{2}$ is not directly computed in the base simulation but potential impacts of heterogeneous loss in the high latitude environment (e.g., Mao et al., 2010) are explored.

Model calculations require constraint to observations of temperature, pressure, $\mathrm{H}_{2} \mathrm{O}, \mathrm{O}_{3}, \mathrm{CO}, \mathrm{NO}, \mathrm{CH}_{4}, \mathrm{NMHCs}$, ketones (acetone and MEK), and alcohols (methanol and ethanol). In addition to these minimum requirements, several additional constraints may be incorporated if desired when measurements are available; these include $\mathrm{CH}_{2} \mathrm{O}, \mathrm{H}_{2} \mathrm{O}_{2}$ and $\mathrm{CH}_{3} \mathrm{OOH}$, nitric acid $\left(\mathrm{HNO}_{3}\right)$, peroxy acetyl nitrate (PAN), and $\mathrm{BrO}$. Constraining parameters are held constant throughout the diurnal cycle with the exception of NO. The total short-lived nitrogen ( $\mathrm{NO}+\mathrm{NO}_{2}+\mathrm{NO}_{3}+2 \mathrm{~N}_{2} \mathrm{O}_{5}+\mathrm{HONO}$ $+\mathrm{HNO}_{4}$ ) is held constant, with partitioning into the individual species calculated by the model throughout the day. The sum total of short-lived nitrogen is determined when NO matches the observed value at the time of measurement.

There are occasions when pronounced heterogeneity of $1 \mathrm{~Hz} \mathrm{NO}$ measurements within the averaged 1 min time span can result in erroneous model predictions of $\mathrm{HO}_{\mathrm{x}}$ and related radical species (Olson et al., 2006). In these cases, the $1 \mathrm{~min}$ average has been broken into 60 one-second points for modeling purposes, using $1 \mathrm{~Hz}$ data for $\mathrm{NO}, \mathrm{O}_{3}, \mathrm{CO}$ and $\mathrm{H}_{2} \mathrm{O}$. The high-resolution model predictions are then 
Table 1. Bromine reactions included in the model.

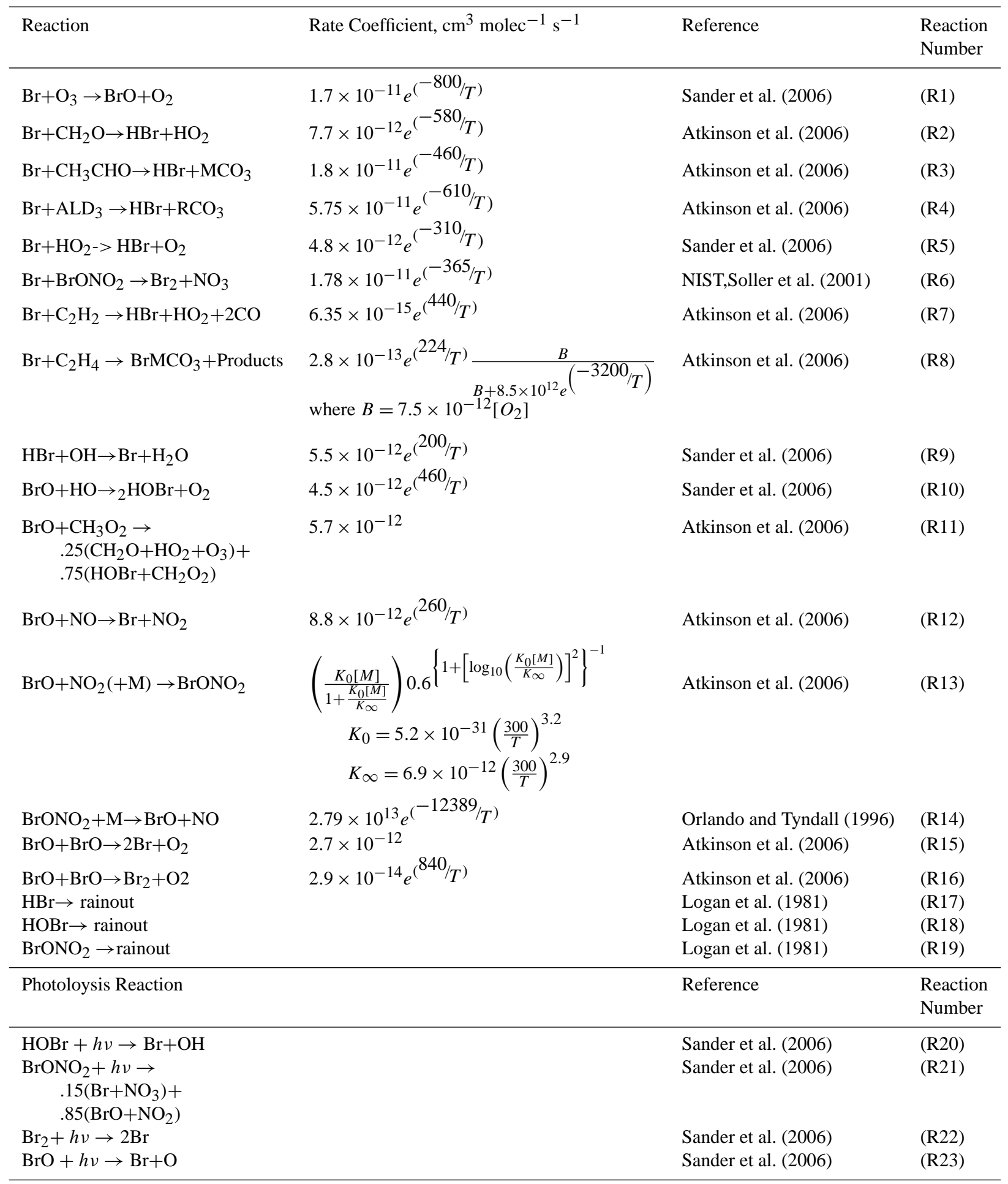

averaged back to the 1 min merge timeline for analysis. The merged data and selected box model results from ARCTAS are available on a public archive (http://www-air.larc.nasa. gov/cgi-bin/arcstat-c).
Sources of uncertainty in model predictions include uncertainties in kinetic and photolytic rate constants, and uncertainties in measurements of constraining observations. Estimates of total model uncertainty are obtained using a Monte Carlo technique and/or a Sensitivity approach. The method 
Table 2. Observations used for Model Constraints and/or Predictive Comparisons.

\begin{tabular}{|c|c|c|}
\hline Species & Institution, Instrument & Reference \\
\hline $\begin{array}{l}\text { Physical parameters } \\
\text { (e.g., UTC, Latitude, Longitude, } \\
\text { Pressure-Altitude, } \\
\text { Temperature, Pressure) }\end{array}$ & NASA DFRC, REVEAL & \\
\hline Overhead $\mathrm{O}_{3}$ Column & NASA, OMI Satellite & http://toms.gsfc.nasa.gov/ \\
\hline Photolysis rates & NCAR, spectral radiometer & Shetter and Muller (1999) \\
\hline \multicolumn{3}{|l|}{ Species for Model Constraint } \\
\hline $\mathrm{H}_{2} \mathrm{O}, \mathrm{CH}_{4}, \mathrm{CO}$ & NASA LaRC, TDLAS & Diskin et al. (2002), Sachse et al. (1987) \\
\hline $\mathrm{O}_{3}, \mathrm{NO}$ & NCAR, Chemiluminescence & Weinheimer et al. (1994) \\
\hline NMHC & UCI, WAS-GC & Blake et al. (2003) \\
\hline Acetone, methanol & U. Innsbrook, PTR-MS & Wisthaler et al. (2002) \\
\hline MEK, ethanol & NCAR, GC-MS (TOGA) & Apel et al. (2003) \\
\hline $\mathrm{BrO}, \mathrm{SO}_{2}$ & Georgia Tech, CIMS & Slusher et al. (2004) \\
\hline \multicolumn{3}{|l|}{$\begin{array}{l}\text { optional constraints } \\
\text { (can also be used for predictive } \\
\text { comparisons): }\end{array}$} \\
\hline PAN & Georgia Tech, CIMS & Slusher et al. (2004) \\
\hline $\mathrm{HNO}_{3}$ & UNH, mist chamber/IC & Scheuer et al. (2003) \\
\hline $\mathrm{CH}_{2} \mathrm{O}$ & NCAR, DFGAS & Webring et al. (2007) \\
\hline Peroxides $\left(\mathrm{H}_{2} \mathrm{O}_{2}, \mathrm{CH}_{3} \mathrm{OOH}\right)$ & Cal Tech, CIMS & Crounse et al. (2006) \\
\hline \multicolumn{3}{|l|}{$\begin{array}{l}\text { Species for predictive } \\
\text { comparisons }\end{array}$} \\
\hline $\mathrm{OH}, \mathrm{HO}_{2}$ & Penn State, LIF (ATHOS) & Faloona et al. (2004) \\
\hline $\mathrm{OH}, \mathrm{HO}_{2}, \mathrm{HO}_{2}+\mathrm{RO}_{2}$ & NCAR, CIMS & Cantrell et al. (2003b) \\
\hline
\end{tabular}

for uncertainty estimation for the LaRC box model is described in more detail in Appendix A.

\subsection{Data}

The data utilized for model constraint and analysis is presented in Table 2. Key measurements for the high latitude $\mathrm{HO}_{\mathrm{x}}$ budget include peroxides $\left(\mathrm{H}_{2} \mathrm{O}_{2}\right.$ in particular) from the CIT-CIMS (California Institute of Technology - chemical ionization mass spectroscopy) instrument, which has a $2 \sigma$ uncertainty of $100 \mathrm{pptv}+50 \%$ of the measurement value (Crounse et al., 2006). Formaldehyde is measured using a difference frequency generation (DFG)/absorption spectroscopy technique (Weibring et al., 2007) with a systematic uncertainty at the $2 \sigma$ level of $12.4 \%$, and a typical 1 min LOD $(2 \sigma)$ of 22 pptv with degradation of the LOD to $\sim 59$ pptv during periods of large changes in aircraft cabin pressure (http://www-air.larc.nasa.gov/cgi-bin/ arcstat-c). Water vapor is obtained from the NASA Langley Research Center DLH (Diode Laser Hygrometer) system with an uncertainty of $10 \%$ (Diskin et al., 2002). The $\mathrm{O}_{3}$ and NO measurements are obtained from the NCAR fourchannel chemiluminescence instrument (Weinheimer et al., 1994) with an $8 \% 2 \sigma$ uncertainty for $\mathrm{O}_{3}$ and a 16 pptv $2 \sigma$ uncertainty for the $60 \mathrm{~s}$ average of NO when NO is less than 100 pptv.

Measurements of $\mathrm{OH}$ and $\mathrm{HO}_{2}$ from the Penn State laser induced fluorescence Airborne Tropospheric Hydrogen Oxide Sensor (ATHOS) are available for comparison to model predictions. The $\mathrm{HO}_{\mathrm{x}}$ measurements have an uncertainty for both species of $\pm 32 \%$, and a limit of detection (LOD) of 0.01 pptv for $\mathrm{OH}$ and 0.1 pptv for $\mathrm{HO}_{2}$ (Brune et al., 1999; Faloona et al., 2004). During ARCTAS, the NCAR CIMS instruments also provided measurements of $\mathrm{OH}$ and $\mathrm{HO}_{2}$ (Cantrell et al., 2003b; Mauldin et al., 1999); however due to some irregularities of the inlet heater, the level of coverage from the CIMS instrument was reduced. This analysis uses the ATHOS $\mathrm{HO}_{\mathrm{x}}$ measurements. Ren et al. (2012) focuses on a comparison between the two independent measurements of $\mathrm{HO}_{\mathrm{x}}$.

NMHC data are taken from the UC Irvine Whole Air Sampling - Gas Chromatography instrument (Blake et al., 2003), and primary data for acetone and methanol are from the University of Innsbrook Proton Transfer Reaction - Mass Spectrometry instrument (Wisthaler et al., 2002). To maximize the total number of points available for modeling, missing data for acetone, methanol, and NMHCs (with the exception of isoprene) are interpolated from adjacent measurements 
within $\pm 5 \mathrm{~min}$ and $\pm 0.5 \mathrm{~km}$. Any remaining missing acetone and methanol are filled where possible using data from the NCAR Trace Organic Gas Analyzer (TOGA) Gas Chromatography - Mass Spectrometry instrument (Apel et al., 2003); TOGA data are used to fill values $4 \%$ of the time during ARCTAS-A and $8.5 \%$ of time during ARCTAS-B. For the few remaining points with missing acetone or methanol data $(0.5 \%$ and $1.5 \%$ during ARCTAS-A and $-\mathrm{B})$, values are filled using observed correlations of PTR-MS acetone or methanol data with CO for each phase of ARCTAS. During ARCTAS-A (spring), the correlations are altitudeindependent, while during ARCTAS-B, separate correlations are derived for the lower troposphere where pollution from biomass burning is prevalent $(\mathrm{CO}>200 \mathrm{pptv})$ and for cleaner portions of the troposphere $(\mathrm{CO}<200 \mathrm{pptv})$.

Methyl-ethyl-ketone (MEK) and ethanol data are taken from the TOGA observations. Where data for MEK are missing $(<2 \%$ of the time for ARCTAS-A and $8 \%$ of the time for ARCTAS-B) values are filled using its observed altitudedependent correlation to acetone for each phase. Missing ethanol ( $<1 \%$ of the time for both phases)is filled using its observed altitude-dependent correlation to methanol.

A percentage of the reported measurements of $\mathrm{NO}$ are negative, particularly during the summer phase: $6 \%$ of the NO is negative during ARCTAS-A and $20 \%$ is negative during ARCTAS-B (see Fig. 2). For modeling purposes, any $1 \mathrm{~min}$ averaged NO less than a threshold value of 1 pptv, including negative values, is set equal to 1 pptv. To test the sensitivity to this choice of minimum threshold, it is varied between 0.1 and 2 pptv. Relative to a 1 pptv threshold, median predictions of $\mathrm{OH}$ for these tests vary less than $8 \%$, and median predictions of $\mathrm{HO}_{2}$ vary less than $2 \%$, all of which are less than the relative differences between predictions and measured values at the low NO points. Note that this is not equivalent to estimating the uncertainty in model predictions due to the total uncertainty in NO observations.

Data points identified as stratospherically influenced are removed from this analysis. Points are considered stratospherically influenced when $\mathrm{O}_{3}>100 \mathrm{ppbv}$ while either $\mathrm{CO}$ $<100$ ppbv or $\mathrm{H}_{2} \mathrm{O}$ is $<$ a threshold value $(50$ ppmv during ARCTAS-A and 100 ppmv during ARCTAS-B). Thirteen percent of the data during ARCTAS-A are identified and removed, and $4 \%$ of the summer data are removed. Because the altitude range of the C-130 used during TOPSE is limited to less than $8 \mathrm{~km}$, instances of stratospheric influence are rare; about $2 \%$ of the TOPSE-sp data are removed, using the same criteria as for ARCTAS-A. In all cases, the latitude range of the considered data is limited to north of $50^{\circ} \mathrm{N}$.
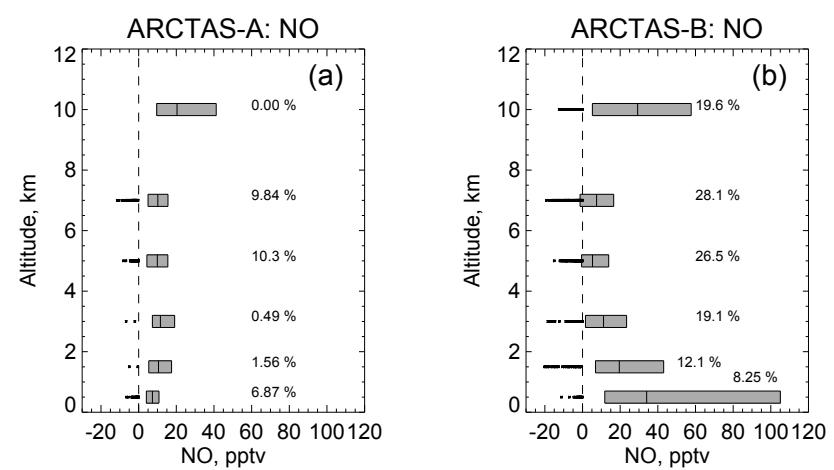

Fig. 2. Range of NO observations during (a) ARCTAS-A and (b) ARCTAS-B for 1-min averages of NO. Bars show the inner 50th percentile range $(25-75 \%)$ and vertical lines within bars indicate the median values. Negative values are shown with black points to the left of the dashed line that indicates zero. The percentage of negative values is indicated at each altitude bin.

\section{Meteorological and photochemical background at high latitudes}

\subsection{Meteorology}

During ARCTAS-A, the general location of the Arctic front was $60^{\circ} \mathrm{N}$ (Fuelberg et al., 2010), and most of the aircraft sampling was well north of that. Therefore most of the data was obtained within the extreme cold and dry air of the Arctic air mass. Springtime values for temperature and moisture at high latitudes during TOPSE-sp were comparable to those during ARCTAS-A (Table 3). Alternately, the median sampled latitude during ARCTAS-B was $57^{\circ} \mathrm{N}$, while the Arctic front was located well to the north of the bulk of sampled latitudes during that period, leading to higher temperatures and moisture relative to the spring campaigns.

Table 3 also shows the median observed photolysis rates for $\mathrm{NO}_{2}\left(\mathrm{~J}-\mathrm{NO}_{2}\right)$ and $\mathrm{O}_{3}\left(\mathrm{~J}-\mathrm{O}^{1} \mathrm{D}\right)$. The near-surface instantaneous observations for $\mathrm{J}-\mathrm{NO}_{2}$ are higher during the spring campaigns (ARCTAS-A and TOPSE-sp) than during summer (ARCTAS-B), while $\mathrm{J}-\mathrm{O}^{1} \mathrm{D}$ shows the opposite tendency. Neglecting transient influences from cloud and aerosols, photolysis is affected by three primary factors: the range of sampled solar zenith angles (SZA), the surface albedo, and the overhead $\mathrm{O}_{3}$ column. While the range of SZA during the spring is limited to higher values (lower photolysis rates), the persistent snow and ice cover significantly enhances the surface albedo and increases photolysis rates. This albedo-driven increase during spring dominates the difference in rates for $\mathrm{J}-\mathrm{NO}_{2}$. While $\mathrm{J}-\mathrm{NO}_{2}$ is relatively unaffected by changes in the overhead $\mathrm{O}_{3}$ column, the larger overhead $\mathrm{O}_{3}$ column during spring $(396 \mathrm{DU})$ relative to summer (316 DU) suppresses J-O ${ }^{1} \mathrm{D}$ and offsets its increase due to the albedo enhancement. 
Table 3. Median meteorological conditions.

\begin{tabular}{lrrrr}
\hline Altitude & Temp (K) & $\mathrm{H}_{2} \mathrm{O}(\mathrm{ppmv})$ & $\begin{array}{r}\text { Inst. J-O } \\
10^{-5} \mathrm{~s}^{-1}\end{array}$ & $\begin{array}{r}\text { Inst. J-NO } \\
10^{-2} \mathrm{~s}^{-1}\end{array}$ \\
\hline \multicolumn{5}{c}{ ARCTAS-A $>50^{\circ} \mathrm{N}$} \\
\hline$>8 \mathrm{~km}$ & 224 & 80 & 1.04 & 1.39 \\
$6-8 \mathrm{~km}$ & 229 & 148 & 0.68 & 1.17 \\
$4-6 \mathrm{~km}$ & 242 & 296 & 0.84 & 1.17 \\
$2-4 \mathrm{~km}$ & 251 & 614 & 0.46 & 0.95 \\
$0-2 \mathrm{~km}$ & 257 & 1270 & 0.46 & 0.91 \\
\hline \multicolumn{5}{c}{ TOPSE-sp (Mar-Apr) $>50^{\circ} \mathrm{N}$} \\
\hline$>8 \mathrm{~km}$ & - & - & - & \\
$6-8 \mathrm{~km}$ & 229 & 161 & 0.71 & 1.06 \\
$4-6 \mathrm{~km}$ & 237 & 225 & 0.56 & 1.08 \\
$2-4 \mathrm{~km}$ & 253 & 869 & 0.44 & 0.93 \\
$0-2 \mathrm{~km}$ & 258 & 1368 & 0.32 & 0.79 \\
\hline \multicolumn{5}{c}{ ARCTAS-B $>50^{\circ} \mathrm{N}$} \\
\hline$>8 \mathrm{~km}$ & 231 & 210 & 1.78 & 1.25 \\
$6-8 \mathrm{~km}$ & 246 & 436 & 2.73 & 1.22 \\
$4-6 \mathrm{~km}$ & 260 & 1783 & 2.14 & 1.06 \\
$2-4 \mathrm{~km}$ & 273 & 6292 & 0.89 & 0.78 \\
$0-2 \mathrm{~km}$ & 285 & 9967 & 1.05 & 0.51 \\
\hline
\end{tabular}

\subsection{Chemical environment}

\subsubsection{Seasonal comparison}

Figures 3-5 show observed profiles of selected species during the spring from ARCTAS-A (dark blue) and from TOPSE-sp (lighter shade of blue). The inner 50th percentile range $(25-75 \%)$ within each altitude bin is shown by the colored bars, and the median value is indicated by the vertical lines within the bars. For seasonal comparison, profiles obtained during the summer (ARCTAS-B) are also shown (red).

During ARCTAS-B, there were a number of episodic encounters with fresh biomass burning plumes, and the influence of biomass burning is prevalent to various extents throughout the region. Data points that are clearly within fresh pollution or biomass burning plumes are identified based on at least one of several thresholds being exceeded: $\mathrm{CO}>300 \mathrm{ppbv}, \mathrm{NO}>500 \mathrm{pptv}$ excluding the upper troposphere, $\mathrm{CH}_{3} \mathrm{CN}>300$ pptv, or benzene $>150$ pptv. Below $2 \mathrm{~km}, 37 \%$ of the data are identified as fresh plumes $(9 \%$ of the data above $2 \mathrm{~km}$ ). The remaining points represent the "background" shown by the bars in Figs. 3-5. The dashed red line in the figures shows the median profile obtained when all data for ARCTAS-B is used, including that from fresh plumes.

Figure $3 \mathrm{a}$ and $\mathrm{b}$ reflect the build-up of longer-lived species (e.g., $\mathrm{CO}$ and $\mathrm{C}_{3} \mathrm{H}_{8}$ ) during winter and early spring. The lifetimes of $\mathrm{CO}$ and the NMHC species (Table 4) are dominated by reaction with $\mathrm{OH}$ and are 3-4 times longer during spring than summer due to the seasonal variation of $\mathrm{OH}$. Long range transport from middle to high latitudes can be important for
Table 4. Diurnally averaged lifetimes (days) based on model calculations.

\begin{tabular}{ccrrrrr}
\hline Altitude & $\mathrm{CO}$ & $\mathrm{C}_{3} \mathrm{H}_{8}$ & $\mathrm{C}_{2} \mathrm{H}_{4}$ & $\mathrm{CH}_{2} \mathrm{O}$ & $\mathrm{H}_{2} \mathrm{O}_{2}$ & $\mathrm{CH}_{3} \mathrm{OOH}$ \\
\hline \multicolumn{7}{c}{ ARCTAS-A } \\
\hline$>4 \mathrm{~km}$ & 220 & 69 & 3.8 & 0.28 & 3.9 & 2.4 \\
$0-4 \mathrm{~km}$ & 213 & 64 & 3.9 & 0.38 & 4.8 & 3.1 \\
\hline \multicolumn{7}{c}{ ARCTAS-B } \\
\hline$>4 \mathrm{~km}$ & 69 & 18 & 1.3 & 0.16 & 1.8 & 1.0 \\
$0-4 \mathrm{~km}$ & 63 & 14 & 1.4 & 0.32 & 3.0 & 1.3 \\
\hline
\end{tabular}

these species with lifetimes greater than a few weeks. Fisher et al. (2010) concluded that long-range transport during this time is predominantly from Europe at altitudes near the surface and from Asia throughout the remaining troposphere. Alternately, the dominant impact of local biomass burning emissions during summer (ARCTAS-B) is clearly shown to dominate profiles of the shorter-lived $\mathrm{C}_{2} \mathrm{H}_{4}$ (Fig. 3c). While middle tropospheric median concentrations of $\mathrm{C}_{2} \mathrm{H}_{4}$ are similarly low during the two seasons, there is a noticeable increase in the range of values from $2-6 \mathrm{~km}$ during ARCTAS$\mathrm{A}$, and $>8 \mathrm{~km}$ during ARCTAS-B. The increased middle tropospheric variability during ARCTAS-A is associated with plumes containing increased $\mathrm{CH}_{3} \mathrm{CN}$, indicating influence from transport of biomass burning emissions, primarily from Asian source regions (Singh et al., 2010; Fisher et al., 2010). During summer, the highest $\mathrm{C}_{2} \mathrm{H}_{4}$ concentrations at upper altitudes are also associated with higher $\mathrm{CH}_{3} \mathrm{CN}$ and $\mathrm{CO}$, consistent with biomass burning pollution. Instances of fast convection of fresh pollution during ARCTAS-B have been identified (e.g., Apel et al., 2012), suggesting that the increased range of values for ethene at upper altitudes during summer is impacted by convection of local biomass burning pollution. $\mathrm{O}_{3}$ profiles are similar throughout the troposphere during both seasons, with surface values near $30 \mathrm{ppbv}$ increasing to $70 \mathrm{ppbv}$ in the upper troposphere (Fig. 3d). The relatively broad 50th percentile range near the surface during the spring is the result of sampling instances of near-surface halogendriven $\mathrm{O}_{3}$ depletion events.

The larger background concentrations and range of NO at low altitudes during ARCTAS-B reflect the pervasive influence from local biomass burning (Fig. 4a). Middle tropospheric concentrations of NO are generally less than 10 20 pptv during both seasons. Browne et al. (2011) determined that both of the $\mathrm{NO}_{2}$ measurements available during ARCTAS are likely to be contaminated by $\mathrm{CH}_{3} \mathrm{O}_{2} \mathrm{NO}_{2}$ at low temperatures. Therefore, the $\mathrm{NO} / \mathrm{NO}_{2}$ ratio shown in Fig. $4 \mathrm{~b}$ is computed using observed $\mathrm{NO}$ and model predictions of $\mathrm{NO}_{2}$. The lower summertime ratio near the surface is impacted equally by the lower near surface $\mathrm{J}-\mathrm{NO}_{2}$ during summer relative to spring (Sect. 3.1) and by the larger summertime concentrations of peroxy radicals, which convert NO to 

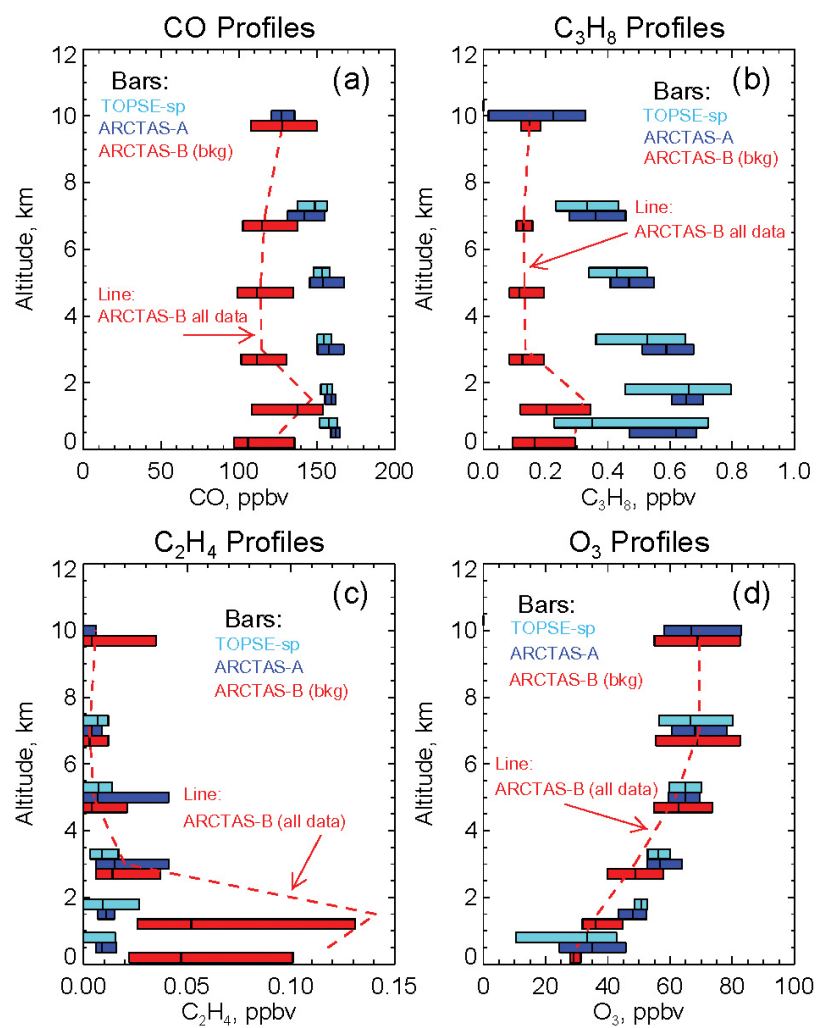

Fig. 3. Profiles of measurements of (a) $\mathrm{CO}$, (b) $\mathrm{C}_{3} \mathrm{H}_{8}$ (c) $\mathrm{C}_{2} \mathrm{H}_{4}$ and (d) $\mathrm{O}_{3}$ during ARCTAS and during TOPSE-sp. Bar plots are as described in Fig. 2. Data for ARCTAS-B shown by the bar plots exclude values identified as within fresh plumes. The dashed lines show the median profile for ARCTAS-B when all data are considered (including fresh plumes).

$\mathrm{NO}_{2}$. Measurements of gas phase $\mathrm{HNO}_{3}$ using the University of New Hampshire mist chamber instrument are shown in Fig. 4c, and indicate similar and consistent concentrations in the upper troposphere of less than $100 \mathrm{pptv}$. The data show flat altitude profiles during spring, and an increase in concentration near the surface during summer.

Figure 5 shows profiles for $\mathrm{HO}_{\mathrm{x}}$ precursor reservoirs $\mathrm{H}_{2} \mathrm{O}_{2}, \mathrm{CH}_{3} \mathrm{OOH}, \mathrm{H}_{2} \mathrm{O}_{2} / \mathrm{CH}_{3} \mathrm{OOH}$ and $\mathrm{CH}_{2} \mathrm{O}$. The relatively short lifetimes for these species shown in Table 4 suggest that long-range transport is unlikely to have a dominant direct impact on concentrations. Concentrations are larger during ARCTAS-B throughout the full extent of the troposphere, reflecting both increased local emission from biomass burning sources and more vigorous photochemical formation in the background atmosphere during the summer.

In comparing the "background" profiles during ARCTAS$\mathrm{B}$ with those using all data, including fresh pollution plumes (dashed red line), it is clear that median values increase in the lowest few $\mathrm{km}$ for $\mathrm{CO}$, NMHCs, $\mathrm{NO}, \mathrm{CH}_{3} \mathrm{OOH}$ and $\mathrm{CH}_{2} \mathrm{O}$ as a result of including pollution plumes. $\mathrm{HNO}_{3}$ and $\mathrm{O}_{3}$ concentrations, however, are relatively unaffected. This
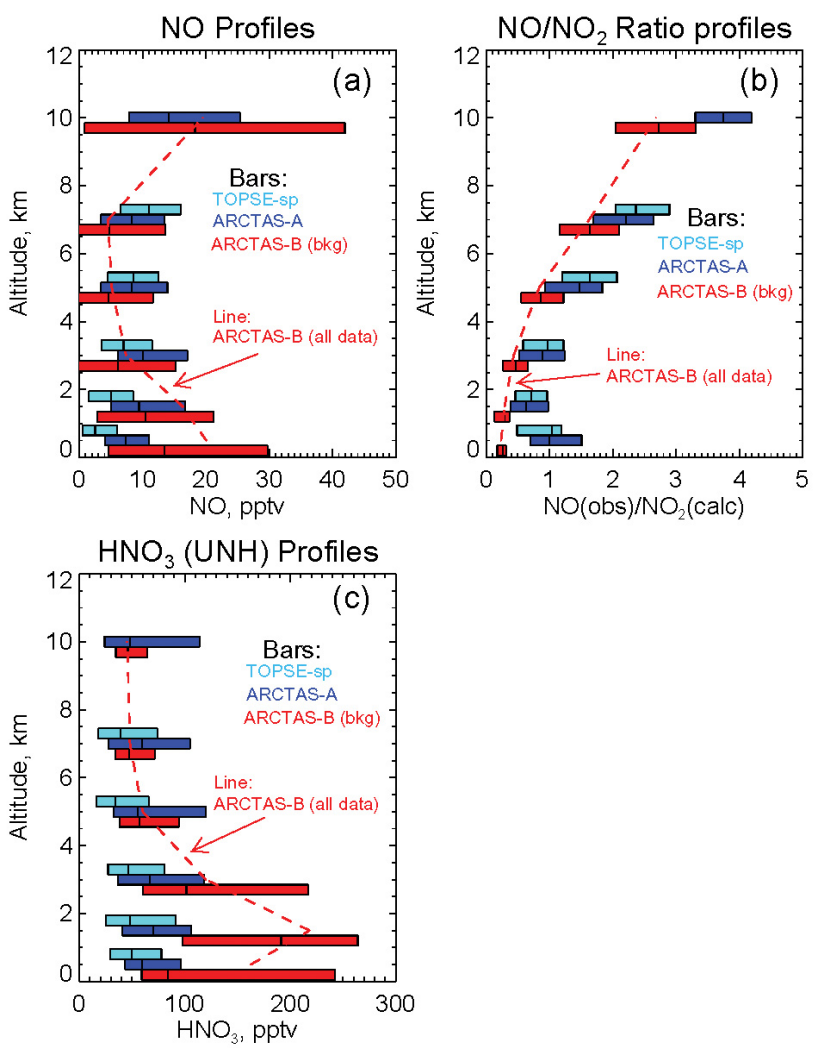

Fig. 4. Profiles of (a) $\mathrm{NO}$, (b) $\mathrm{NO} / \mathrm{NO}_{2}$ and (c) $\mathrm{HNO}_{3}$ during $\mathrm{ARC}$ TAS and during TOPSE-sp. Bar plots and dashed lines are as described in Fig. 3.

implies there is little impact on net $\mathrm{O}_{3}$ production within the biomass burning plumes, consistent with the analysis of Singh et al. (2010).

\subsubsection{TOPSE-sp versus ARCTAS-A}

The data in Table 3 and Figs. 3-5 indicate that the air masses sampled during ARCTAS-A and TOPSE-sp were highly similar in meteorological and photochemical characteristics, with the exception of peroxides. Median observations for $\mathrm{H}_{2} \mathrm{O}_{2}$ during ARCTAS-A were 300-450 pptv throughout the free troposphere, which are 2.5 to 3 times higher than those during TOPSE-sp (100-200 pptv). Measurements from the Atmospheric Chemistry Experiment satellite (ACE; Rinsland et al., 2007) suggest a rapid seasonal change of peroxides in the upper Arctic troposphere between March and May, which would create the possibility of a timing bias between ARCTAS-A and TOPSE; however both of the March and the April profiles from TOPSE remain distinctly lower than that from ARCTAS-A (Fig. 6) and the difference between March and April TOPSE data above $4 \mathrm{~km}$ is minimal.

If the differences in $\mathrm{H}_{2} \mathrm{O}_{2}$ between the campaigns are due to a significant difference in rainout history between TOPSE and ARCTAS-A, these differences should also be reflected in 

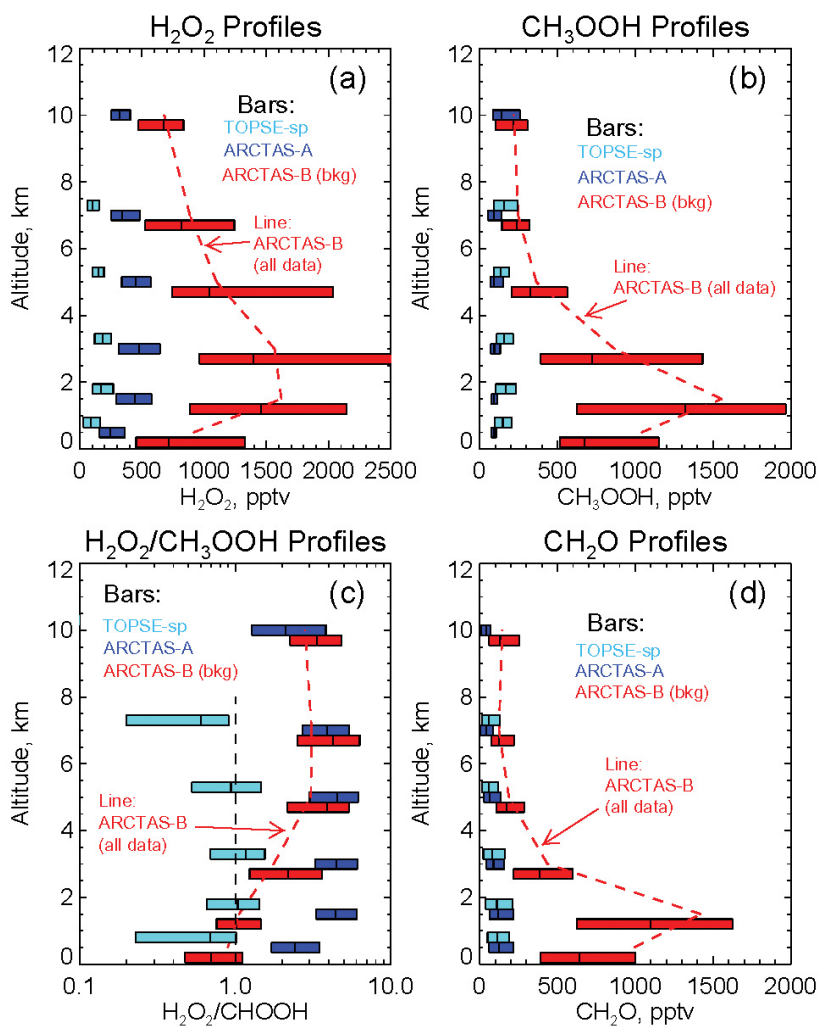

Fig. 5. Profiles of (a) $\mathrm{H}_{2} \mathrm{O}_{2}$, (b) $\mathrm{CH}_{3} \mathrm{OOH}$, (c) $\mathrm{H}_{2} \mathrm{O}_{2} / \mathrm{CH}_{3} \mathrm{OOH}$, and (d) $\mathrm{CH}_{2} \mathrm{O}$ during ARCTAS-A and $-\mathrm{B}$ and during TOPSE-sp. Bar plots and dashed lines are as described in Fig. 3.

other soluble species, notably $\mathrm{HNO}_{3}$ and to a lesser extent, $\mathrm{CH}_{3} \mathrm{OOH}$. Figure $4 \mathrm{c}$ shows slightly lower median values of $\mathrm{HNO}_{3}$ during TOPSE relative to ARCTAS-A; however, the ambient variability for both campaigns indicated by the 50th percentile ranges is heavily overlapping, while there is a clear separation between peroxide ranges of ambient variability between the two campaigns. Further, a reverse bias is seen for $\mathrm{CH}_{3} \mathrm{OOH}$, with observations during ARCTAS-A being $50-75 \%$ lower than those during TOPSE-sp, which is not supportive of an increased role for rainout during TOPSE. As a result of the different biases for the two peroxides, the $\mathrm{H}_{2} \mathrm{O}_{2} / \mathrm{CH}_{3} \mathrm{OOH}$ ratios in the free troposphere are dramatically different for the two spring campaigns, with values of 3-4 during ARCTAS-A, and values near one during TOPSEsp. The similarity in $\mathrm{CO}, \mathrm{NO}$, and NMHC observations during the two spring campaigns precludes a significant difference due to transport source regions. Given the similarities in physical conditions $\left(\mathrm{H}_{2} \mathrm{O}\right.$, temperature, radiation) and in other species important in the photochemical budget of peroxides $\left(\mathrm{O}_{3}, \mathrm{CO}, \mathrm{CH}_{2} \mathrm{O}\right)$, it is difficult to identify a physical reason that peroxides would show such significant differences between the two campaigns.

$\mathrm{H}_{2} \mathrm{O}_{2}$ measurements during ARCTAS were obtained from both the single-quad and triple-quad implementations of the

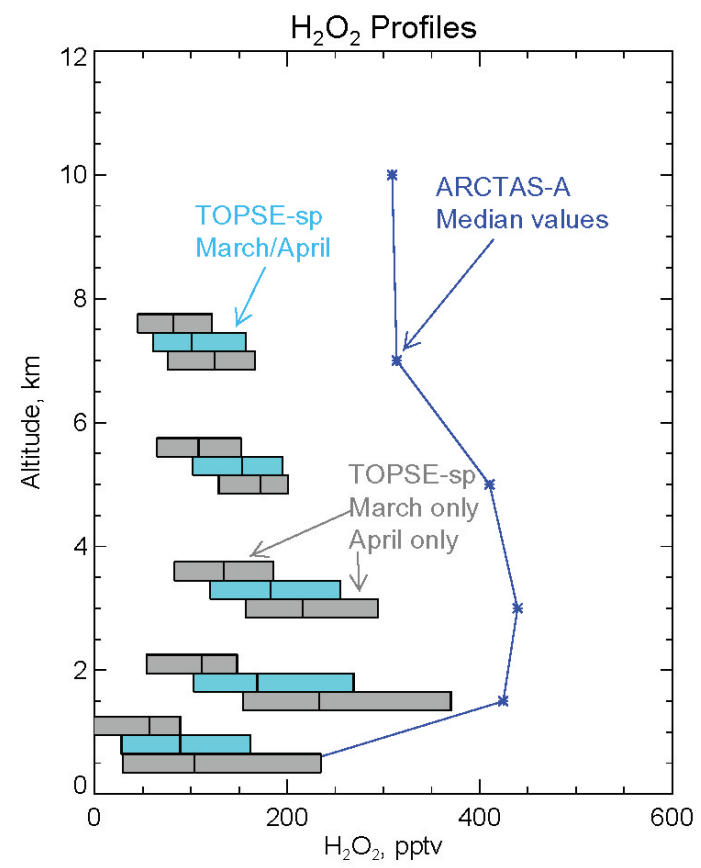

Fig. 6. Median observations of $\mathrm{H}_{2} \mathrm{O}_{2}$ during ARCTAS-A and during TOPSE-sp, using combined March/April data versus March only and April only.

CIMS instruments, which use independent calibrations for $\mathrm{H}_{2} \mathrm{O}_{2}$ determinations (Crounse et al., 2006). The two measurements show a high correlation to each other, with no significant bias. The measurements of peroxides during TOPSEsp were obtained using the University of Rhode Island's instrument utilizing High Performance Liquid Chromatography (URI-HPLC) (Lee et al., 1995; Snow et al., 2003). Both the URI-HPLC instrument and the CIT-CIMS instruments were onboard the DC-8 during NASA's 2004 INTEXNA campaign (Singh et al., 2006; Snow et al., 2007), during which the two instruments compared well. The median value of $\mathrm{H}_{2} \mathrm{O}_{2}$ at altitudes $>6 \mathrm{~km}$ during INTEX-A was 337 pptv, within the range of concentrations measured during ARCTAS-A. At these lower-concentrations, the fit of CITCIMS data to the URI-HPLC data gives a slope of 0.87 and an intercept of $38 \mathrm{pptv}$. The median ratio between the two peroxide measurements is 0.98 , and the $r^{2}$ is 0.85 , suggesting no bias between the two instruments during INTEX-NA. The cause of the difference in $\mathrm{H}_{2} \mathrm{O}_{2}$ of several hundred pptv in the free troposphere during ARCTAS-A and TOPSE-sp is unresolved, and, as will be shown, has important implications for conclusions related to the Arctic $\mathrm{HO}_{\mathrm{x}}$ budget.

\section{Assessment of $\mathrm{HO}_{\mathrm{x}}$ photochemistry}

For the purpose of a comparison of $\mathrm{HO}_{\mathrm{x}}$ observations during ARCTAS to model predictions, the box model is run with full constraints, including $\mathrm{CH}_{2} \mathrm{O}$. The analysis is limited to the 
subset of data points that include measurements of the major reservoir $\mathrm{HO}_{\mathrm{x}}$ precursors $\left(\mathrm{CH}_{2} \mathrm{O}\right.$ and $\mathrm{H}_{2} \mathrm{O}_{2}$, discussed in Sect. 4.1). The other constraints $\left(\mathrm{CH}_{3} \mathrm{OOH}, \mathrm{PAN}\right.$ and $\left.\mathrm{HNO}_{3}\right)$ are used when measurements are available. With these restrictions, there are a total of 1928 ATHOS $\mathrm{HO}_{\mathrm{x}}$ measurements available for analysis during ARCTAS-A and 2101 during ARCTAS-B.

\section{1 $\mathrm{HO}_{\mathrm{x}}$ sources}

Because of the rapid cycling between $\mathrm{OH}$ and $\mathrm{HO}_{2}$, it is useful to examine the source of the combined radicals $\left(\mathrm{HO}_{\mathrm{x}}=\mathrm{OH}+\mathrm{HO}_{2}\right)$. Primary sources of $\mathrm{HO}_{\mathrm{x}}$ include $\mathrm{O}_{3}$ photolysis in the presence of water vapor, the photolysis of ketones (particularly acetone), and ozonolysis of alkenes. Additionally, $\mathrm{HO}_{\mathrm{x}}$ reservoir species such as $\mathrm{H}_{2} \mathrm{O}_{2}$, $\mathrm{CH}_{3} \mathrm{OOH}, \mathrm{CH}_{2} \mathrm{O}$ and $\mathrm{HO}_{2} \mathrm{NO}_{2}$ formed during $\mathrm{HO}_{\mathrm{x}}$ cycling are a source of $\mathrm{HO}_{\mathrm{x}}$ upon photolysis. The source of $\mathrm{HO}_{\mathrm{x}}$ originating from multiple species flows through $\mathrm{CH}_{2} \mathrm{O}$ (e.g., $\mathrm{NMHC}$, and branches from $\mathrm{CH}_{3} \mathrm{OOH}$ and acetone). The constraint of $\mathrm{CH}_{2} \mathrm{O}$ to observations in these model simulations, rather than allowing the model to predict concentrations of $\mathrm{CH}_{2} \mathrm{O}$, limits the ability to segregate $\mathrm{HO}_{\mathrm{x}}$ sources from $\mathrm{CH}_{2} \mathrm{O}$ into the individual initiating species. Figure 7 shows median profiles of the following instantaneous $\mathrm{HO}_{\mathrm{x}}$ sources calculated from observations: the primary source stemming from $\mathrm{O}_{3}$ photolysis, the radical channel of $\mathrm{CH}_{2} \mathrm{O}$ photolysis, the branch of $\mathrm{CH}_{3} \mathrm{OOH}$ photolysis that does not flow through $\mathrm{CH}_{2} \mathrm{O}$ (i.e., that which is not already included implicitly in the calculated source from constrained $\mathrm{CH}_{2} \mathrm{O}$ ), and the photolysis of $\mathrm{H}_{2} \mathrm{O}_{2}$ and $\mathrm{HO}_{2} \mathrm{NO}_{2}$. The source from ketones and ozonolysis of alkenes are minor contributors and are not shown.

The total $\mathrm{HO}_{\mathrm{x}}$ source during ARCTAS-B is nearly an order of magnitude larger than during ARCTAS-A in the boundary layer, and is larger by a factor of 4 in the free troposphere. Dry conditions and low $\mathrm{J}-\mathrm{O}^{1} \mathrm{D}$ photolysis rates during spring result in a suppressed primary source for $\mathrm{HO}_{\mathrm{x}}$ from $\mathrm{O}\left({ }^{1} \mathrm{D}\right)+\mathrm{H}_{2} \mathrm{O}$ in the free troposphere, amplifying the importance of the reservoir sources. The flow through $\mathrm{CH}_{2} \mathrm{O}$ is the second largest $\mathrm{HO}_{\mathrm{x}}$ source in the free and upper troposphere, at about $25 \%$ of the total during both seasons. The source from $\mathrm{H}_{2} \mathrm{O}_{2}$ is the largest component of the $\mathrm{HO}_{\mathrm{x}}$ source in the middle and upper troposphere, at $45 \%$ during spring and $30 \%$ during summer. This emphasizes the importance of differences in $\mathrm{H}_{2} \mathrm{O}_{2}$ measurements during ARCTAS-A and TOPSE, as it has potential consequences for the total $\mathrm{HO}_{\mathrm{x}}$ source.

\subsection{Model versus observations of $\mathrm{HO}_{\mathrm{x}}$}

Observations of $\mathrm{OH}$ and $\mathrm{HO}_{2}$ are shown by the bar plots in Fig. 8a and b. During ARCTAS-A, concentrations of $\mathrm{OH}$ are markedly low. Twenty percent of all $\mathrm{OH}$ observations are at LOD $(\leq 0.01 \mathrm{pptv})$, and nearly $40 \%$ of the $\mathrm{OH}$ measure-
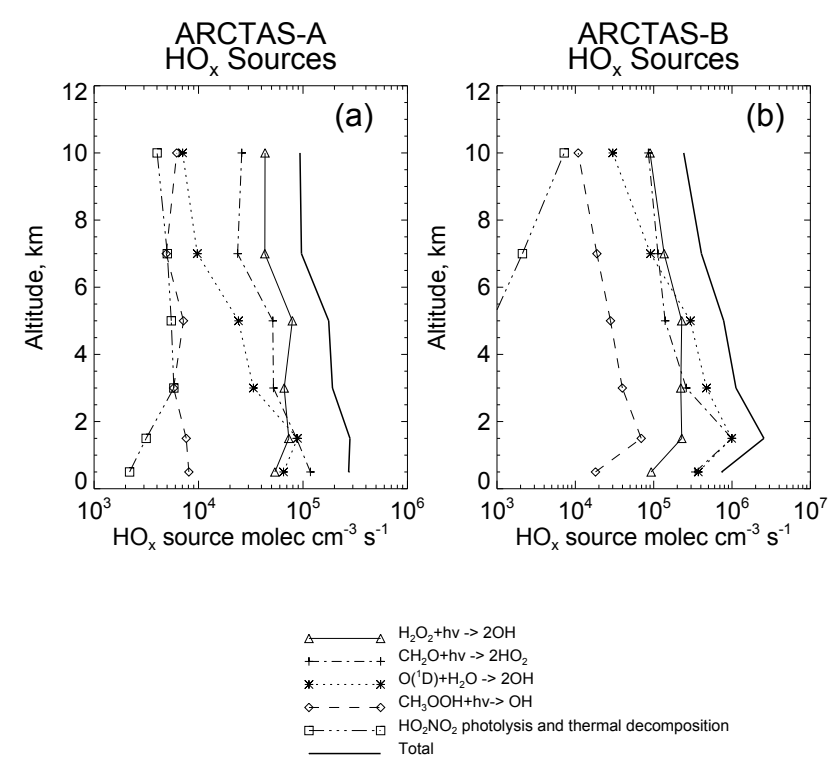

Fig. 7. Gross $\mathrm{HO}_{\mathrm{x}}$ production during (a) ARCTAS-A and (b) ARCTAS-B.

ments below $2 \mathrm{~km}$ are at LOD. OH concentrations generally increase with altitude. During ARCTAS-B, OH maximizes in the middle troposphere at concentrations more than 4 times larger than those during spring. While springtime values of $\mathrm{HO}_{2}$ are uniformly low with no vertical gradient (median values are 4 pptv or less), summertime values are largest near the surface (16.7 pptv) and decrease to 7-8 pptv above $8 \mathrm{~km}$.

Median model predictions of $\mathrm{OH}$ and $\mathrm{HO}_{2}$ from the fully constrained model are shown by the bars in Fig. 8c and d. The thin solid lines in the figures reproduce the median observed profiles shown in the upper panels for direct comparison. Both the median concentrations and altitude gradient of $\mathrm{OH}$ are well represented by the box model during ARCTAS-A, with a median R-Obs/Calc $(\mathrm{OH})$ of 0.96. Alternately, predictions of $\mathrm{OH}$ during ARCTAS-B show a gradual increase with altitude, and are generally biased lower than observations. Predictions of $\mathrm{HO}_{2}$ are significantly and consistently larger than observations throughout the full middle and upper troposphere during both phases. The overestimate of $\mathrm{HO}_{2}$ persists down to the surface during ARCTASA. For further comparison, Fig. 9 shows scatterplots of observed and modeled values for $\mathrm{OH}$ and for $\mathrm{HO}_{2}$ during the two phases. Tables 5 and 6 quantify statistical quantities (median R-Obs/Calc and $r^{2}$ ), calculated using the full set of model/measurement pairs within various altitude bins. The number of $\mathrm{OH}$ observations at LOD during ARCTAS-A (often reported as negative values) makes interpretation of $\mathrm{R}$ Obs/Calc problematic. In the cases where both the $\mathrm{OH}$ measurement and the model calculation are less than the instrument LOD of $0.01 \mathrm{pptv}$ the two values are assumed to agree and a value of " 1 " is assigned for R-Obs/Calc. The correlation between measurements and model predictions 
Table 5. Median Observed-to-Calculated Ratios and $\left(r^{2}\right)$ for $\mathrm{HO}_{\mathrm{x}}$.

\begin{tabular}{|c|c|c|}
\hline \multicolumn{3}{|c|}{ ARCTAS-A } \\
\hline Altitude & $\begin{array}{c}\mathrm{OH} \\
(\mathrm{ATHOS}) \\
\text { R-Obs/Calc }\left(r^{2}\right)\end{array}$ & $\begin{array}{c}\mathrm{HO}_{2} \\
(\mathrm{ATHOS}) \\
\text { R-Obs/Calc }\left(r^{2}\right)\end{array}$ \\
\hline$>8 \mathrm{~km}$ & $0.85(0.64)$ & $0.49(0.74)$ \\
\hline $6-8 \mathrm{~km}$ & $0.91(0.64)$ & $\mathbf{0 . 5 2}(0.85)$ \\
\hline $4-6 \mathrm{~km}$ & $1.00(0.71)$ & $\mathbf{0 . 5 8}(0.86)$ \\
\hline $2-4 \mathrm{~km}$ & $\mathbf{0 . 8 9}(0.38)$ & $\mathbf{0 . 6 7}(0.84)$ \\
\hline $1-2 \mathrm{~km}$ & $0.74(0.04)$ & $0.66(0.58)$ \\
\hline $0-1 \mathrm{~km}$ & $1.00(0.18)$ & $0.71(0.67)$ \\
\hline
\end{tabular}
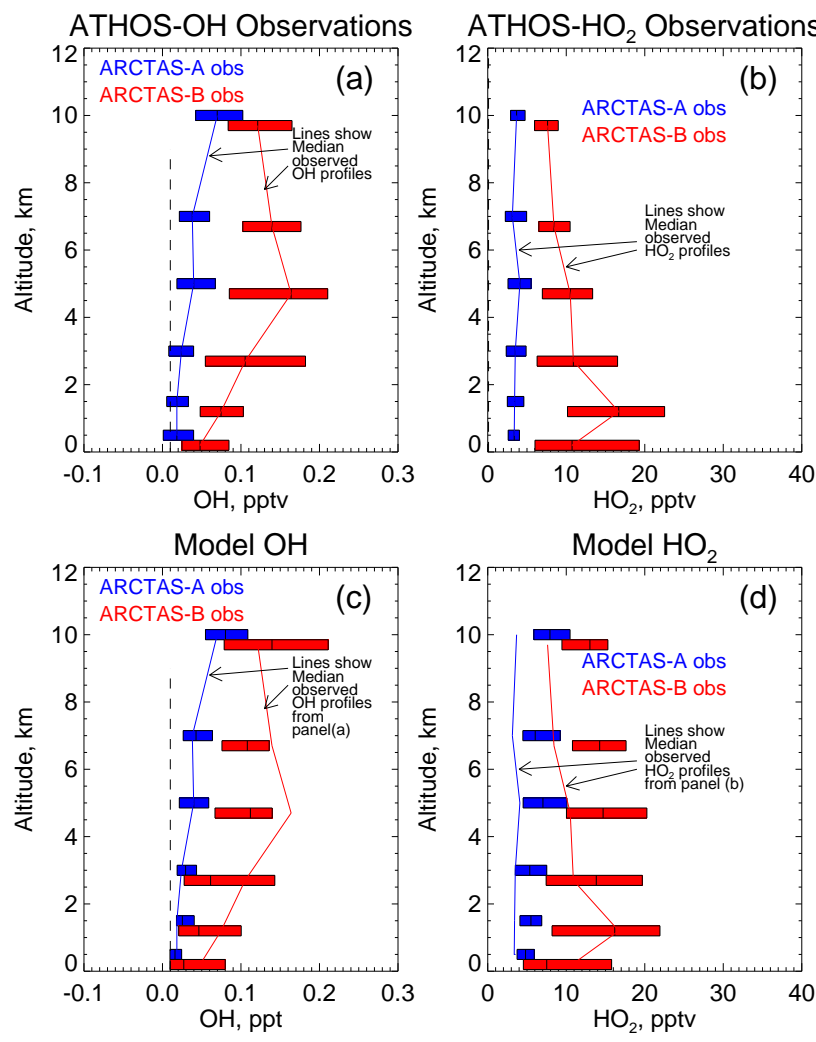

Fig. 8. Profiles of observed (a) $\mathrm{OH}$ and (b) $\mathrm{HO}_{2}$ and of modelpredicted (c) $\mathrm{OH}$ and (d) $\mathrm{HO}_{2}$ during ARCTAS. Bar plots are as described in Fig. 2. The lines indicate the median observed profiles of $\mathrm{OH}$ and $\mathrm{HO}_{2}$.

$\left(r^{2}\right)$ decreases for $\mathrm{OH}$ at low altitudes, particularly during ARCTAS-A. While there is an offset between model predictions and observations of $\mathrm{HO}_{2}$ throughout most of the domain, the correlation between the two is uniformly high during both phases.

Recent work by Fuchs et al. (2011) show that $\mathrm{HO}_{2}$ measurement techniques using chemical conversion to $\mathrm{OH}$ through the addition of NO such as is used for ATHOS are likely to suffer interferences from aromatic-, alkene-, and
Table 6. Median Observed-to-Calculated Ratios and $\left(r^{2}\right)$ for $\mathrm{HO}_{\mathrm{x}}$.

\begin{tabular}{ccc}
\hline & ARCTAS-B & \\
\hline Altitude & OH & $\mathrm{HO}_{2}$ \\
& $\begin{array}{c}\text { (ATHOS) } \\
\text { R-Obs/Calc }\left(r^{2}\right)\end{array}$ & R-Obs/Calc $\left(r^{2}\right)$ \\
\hline$>8 \mathrm{~km}$ & $\mathbf{0 . 8 8}(0.73)$ & $\mathbf{0 . 6 0}(0.76)$ \\
$6-8 \mathrm{~km}$ & $\mathbf{1 . 2 7}(0.50)$ & $\mathbf{0 . 6 1}(0.76)$ \\
$4-6 \mathrm{~km}$ & $\mathbf{1 . 4 5}(0.61)$ & $\mathbf{0 . 7 3}(0.85)$ \\
$2-4 \mathrm{~km}$ & $\mathbf{1 . 3 2}(0.53)$ & $\mathbf{0 . 8 6}(0.82)$ \\
$1-2 \mathrm{~km}$ & $\mathbf{1 . 4 8}(0.50)$ & $\mathbf{1 . 1 0}(0.78)$ \\
$0-1 \mathrm{~km}$ & $\mathbf{1 . 4 6}(0.59)$ & $\mathbf{1 . 2 8}(0.89)$
\end{tabular}

isoprene-based peroxy radicals $\left(\mathrm{RO}_{2}\right)$, resulting in a high bias for the $\mathrm{HO}_{2}$ measurement. Interferences due to $\mathrm{RO}_{2}$ from smaller alkanes such as methane and ethane are negligible. During ARCTAS, because the $\mathrm{HO}_{2}$ observations are persistently lower than the model predictions, any interference from $\mathrm{RO}_{2}$ radicals would only exacerbate the observed to modeled discrepancies. During the summer phase ARCTAS$\mathrm{B}$ and primarily in the boundary layer, about $17 \%$ of the data were comprised of total $\mathrm{RO}_{2}$ dominated by those from alkene, isoprene, and aromatic chemistry, as predicted by the model. Interestingly, the median R-Obs/Calc for $\mathrm{HO}_{2}$ for those points is about $25 \%$ larger than that for points where $\mathrm{RO}_{2}$ is dominated by small alkanes, implying an increase in the observation value relative to the model prediction, consistent with the bias identified by Fuchs et al. (2011). Cases where $\mathrm{RO}_{2}$ is dominated by alkenes, isoprene and aromatic chemistry are rare in the free troposphere during ARCTAS$\mathrm{B}$, and negligible during ARCTAS-A.

In addition, recent work by Mao et al. (2012) have recently reported that ground based $\mathrm{OH}$ measurements by the Penn State LIF instrument may be subject to an interference related to biogenic volatile organic compounds, particularly at higher temperatures. Very few biogenic hydrocarbons were measured during ARCTAS-A, so this interference should be negligible for that data set. There were more biogenic compounds measured during ARCTAS-B, though at relatively low temperatures; Ren et al. (2012) determine that the level of this interference during ARCTAS cannot be quantified at this time.

Few data sets are available for comparison to these results that include simultaneous measurements of $\mathrm{HO}_{\mathrm{x}}$ and its precursors in the free troposphere of the Arctic. A comparison of the ATHOS-LIF $\mathrm{HO}_{\mathrm{x}}$ measurements to those from the previously described CIMS instrument which was also on board the DC- 8 aircraft during ARCTAS are discussed in detail by Ren et al. (2012). That study shows that CIMS measurements of $\mathrm{HO}_{2}$ were generally higher than measurements from ATHOS-LIF, with median ratios of $\left[\mathrm{HO}_{2}\right]_{\mathrm{CIMS}} /\left[\mathrm{HO}_{2}\right]_{\mathrm{LIF}}$ of 1.65 during ARCTAS-A and1.28 during ARCTAS-B. This results in a median value for R-Obs/Calc $\left(\mathrm{HO}_{2}\right)$ within $10 \%$ 

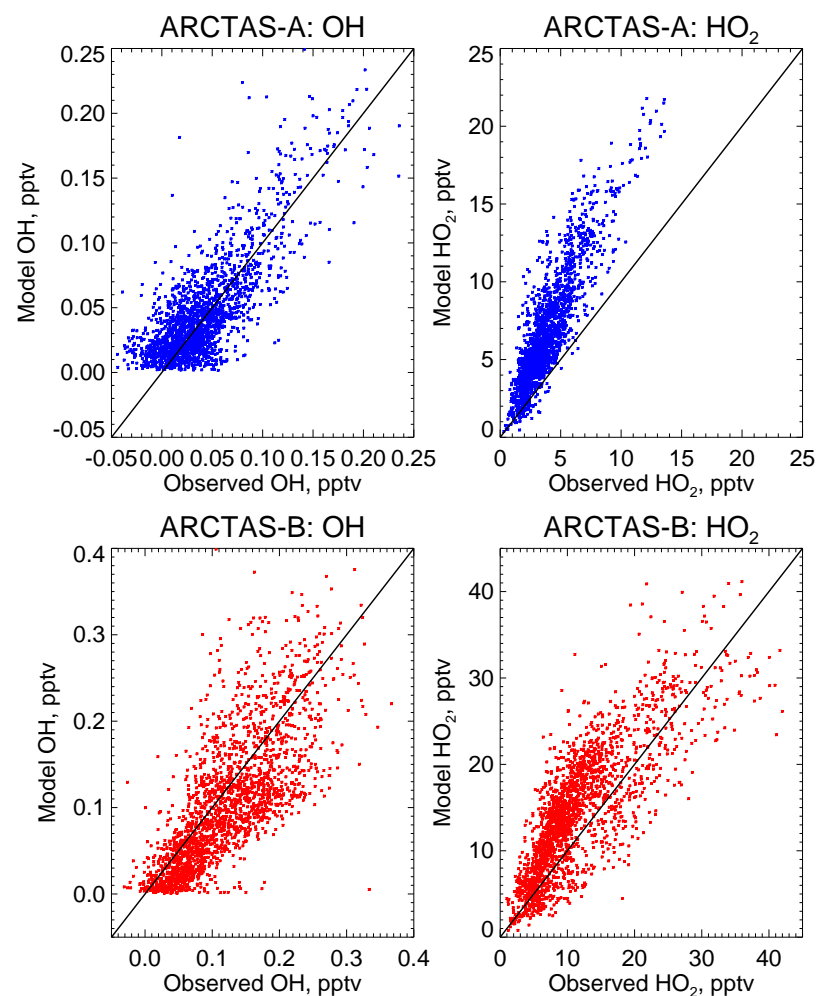

Fig. 9. Scatter plot of observed versus model-predicted (a) $\mathrm{OH}$ and (b) $\mathrm{HO}_{2}$ during ARCTAS-A, and (c) $\mathrm{OH}$ and (d) $\mathrm{HO}_{2}$ during ARCTAS-B. The one-to-one line is shown in black.

of 1 from the surface through $8 \mathrm{~km}$ during ARCTAS-A, compared to values from 0.5 to 0.7 for the ATHOS-LIF $\left(\mathrm{HO}_{2}\right)$ measurements described above and in Table 3.

The same CIMS instrument was used during the TOPSE campaign, including measurements of $\mathrm{HO}_{2}+\mathrm{RO}_{2}$ (Cantrell et al., 2003a), though the number of points available for modeling that include both $\mathrm{HO}_{2}+\mathrm{RO}_{2}$ observations and the major precursors $\left(\mathrm{H}_{2} \mathrm{O}_{2}\right.$ and $\left.\mathrm{CH}_{2} \mathrm{O}\right)$ is limited to less than 200 points. While the CIMS data gave R-Obs/Calc $\left(\mathrm{HO}_{2}\right)$ values near 1 during ARCTAS-A, values of R-Obs/Calc $\left(\mathrm{HO}_{2}+\mathrm{RO}_{2}\right)$ from TOPSE (using the current version of the LaRC model) range from 0.64 at the surface to 0.38 at $6-$ $8 \mathrm{~km}$, more similar to the values using ATHOS-LIF measurements during ARCTAS-A. Note, however, that there is a considerable amount of scatter in this comparison $\left(r^{2}=0.35\right)$, compared to the highly correlated model-measurements pairs during ARCTAS with $r^{2}=0.75$ to 0.85 in the free troposphere.

\subsubsection{OH during ARCTAS-A}

To better quantify the amount of scatter in the $\mathrm{OH}$ observations during ARCTAS-A, Fig. 10 shows the $\mathrm{OH}$ observations plotted as a function of sorted (increasing) model predictions. Sorted model values are shown with black points.

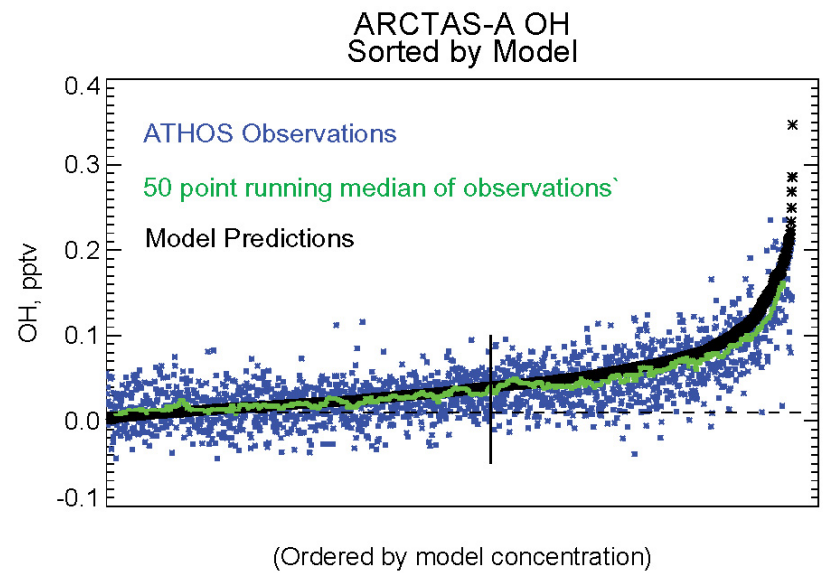

Fig. 10. Observed (blue) and model-predicted (black) concentration pairs of $\mathrm{OH}$ during ARCTAS-A sorted by increasing model concentration. The green line shows a 50 point running median of observations along the sorted values.

All data values (blue points) are retained as reported, including those below LOD. A running median of the observations along this sorted series is calculated using a bin size of 50 and is shown with the green line. There is no bias between this running median of observations and the sorted model values at low concentrations. Below an arbitrary threshold value of 0.04 pptv (vertical line in Fig. 10), the median R-Obs/Calc is 1.0 , while the model over predicts $\mathrm{OH}$ at higher concentrations (median R-Obs/Calc of 0.86). Note that the previously described assumption of R-Obs/Calc $=1$ for points where both the model and the observation is at or below LOD affects about $8 \%$ of the points below the threshold. When that assumption is removed, the median R-Obs/Calc changes only slightly to 0.98 .

The scatter of observations around the model predictions is large compared to the instrument LOD. For the subset of data below the selected threshold, $98 \%(2 \sigma)$ of the observations are contained within \pm 0.05 pptv around model predictions ( $68 \%$ or $1 \sigma$ are within \pm 0.022 pptv). Because the scatter is symmetric around the model predictions, it is unlikely that a single missing process in the model, such as missing measurements of BrO, can explain the scatter. The $2 \sigma$ total uncertainties in model predictions of $\mathrm{OH}$ are of similar magnitude, ranging from 0.03 to $0.05 \mathrm{pptv}$ (see Appendix A and Table A2). These levels of observational scatter and model uncertainty are at the order of magnitude of the ambient observations. Below $2 \mathrm{~km}$, for example, more than $85 \%$ of the $\mathrm{OH}$ observations are less than $0.05 \mathrm{pptv}$, and nearly $60 \%$ are less than $0.022 \mathrm{pptv}$. This suggests that at lower altitudes during ARCTAS-A, the practicality of observationally-based analysis using $\mathrm{OH}$ data is limited. 


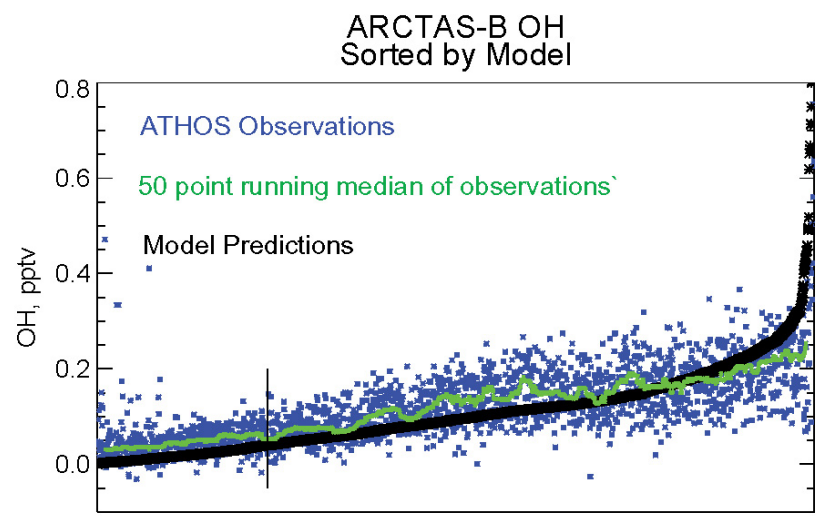

(Ordered by model concentration)

Fig. 11. Observed (blue) and model-predicted (black) concentrations pairs of $\mathrm{OH}$ during ARCTAS-B sorted by increasing model concentration. The green line shows a 50 point running median of observations along the sorted values.

\subsubsection{OH during ARCTAS-B}

During ARCTAS-B, the model persistently under predicts $\mathrm{OH}$ for all but the highest altitudes (see Fig. 8c), with an overall R-Obs/Calc of 1.25 . The scatter of observations around sorted model concentrations for ARCTAS-B is shown in Fig. 11. In contrast to ARCTAS-A, there is a clear bias toward model under prediction at the lower concentrations (retaining the threshold of $0.04 \mathrm{pptv}$ identified in Sect. 4.3.1), with a median R-Obs/Calc of 2.5. This model under prediction holds throughout most of the range of model predictions, with a switch to over predictions evident only at the highest concentrations. Some recent studies have suggested that at high solar zenith angles, an additional source of $\mathrm{OH}$ from the reaction of electronically exited $\mathrm{NO}_{2}$ with $\mathrm{H}_{2} \mathrm{O}$ may result in a source of $\mathrm{OH}$ and $\mathrm{HONO}$ that rivals the magnitude of the primary source from $\mathrm{O}\left({ }^{1} \mathrm{D}\right)+\mathrm{H}_{2} \mathrm{O}$ (Li et al., 2008), although subsequent studies have suggested that the reaction is unlikely to occur in the atmosphere (Carr et al., 2009). However, including this source in the box model made negligible difference in radical production for ARCTAS-B conditions.

The source of $\mathrm{OH}$ is strongly impacted by the recycling of $\mathrm{HO}_{2}$, which is significantly over predicted at higher altitudes and slightly under predicted at the surface during ARCTASB (Fig. 8d). To minimize the impact of imperfect predictions of $\mathrm{HO}_{2}$ on predictions of $\mathrm{OH}$, it is useful to examine the predicted and observed $\mathrm{HO}_{2} / \mathrm{OH}$ ratios. Figure 12a shows that there is a clear tendency of the model to overestimate $\mathrm{HO}_{2} / \mathrm{OH}$ at low NO. Further, discussion in Appendix A and Fig. A2 shows that the uncertainty in the NO measurement dominates the uncertainty in model predictions of $\mathrm{OH}$, and that the uncertainty increases with lower NO concentrations. A sensitivity simulation is run whereby NO is universally increased by $16 \mathrm{pptv}$ (the $2 \sigma$ uncertainty of the NO measure-

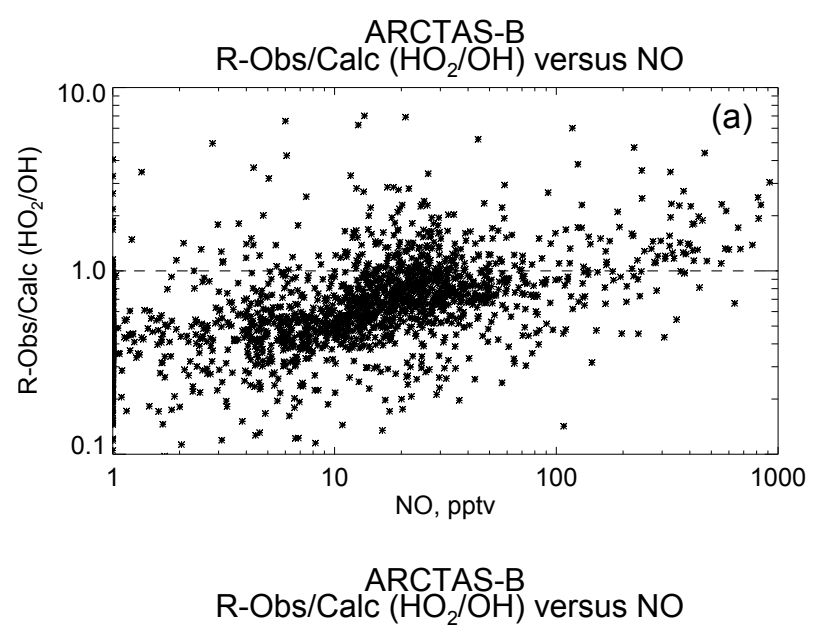

(Sensitivity: NO increased by 16 pptv)

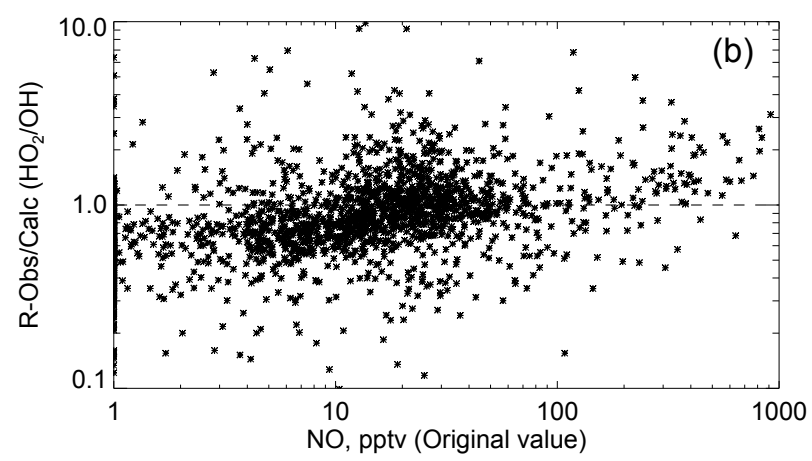

Fig. 12. Observed-to-calculated ratio of the $\mathrm{HO}_{2} / \mathrm{OH}$ partitioning during ARCTAS-B as a function of NO. Results from the standard model simulation are shown in (a) and results when NO is universally increased by $16 \mathrm{pptv}$ are shown in (b).

ment at concentrations less than $100 \mathrm{pptv})$. For this test simulation, the overall median $\mathrm{R}-\mathrm{Obs} / \mathrm{Calc}$ for $\mathrm{OH}$ decreases from 1.25 to 0.9 with a dependence on $\mathrm{NO}$ concentration. Figure $12 \mathrm{~b}$ shows the resulting R-Obs/Calc $\left(\mathrm{HO}_{2} / \mathrm{OH}\right)$. There is currently no reason to suspect a bias in the measurement of NO during ARCTAS-B. However, given the high sensitivity of $\mathrm{OH}$ predictions to changes of $\mathrm{NO}$ within the bounds of the uncertainty of the measurement, it is difficult to more rigorously diagnose the cause of the persistent under prediction of OH during ARCTAS-B.

\subsubsection{Impact of $\mathrm{BrO}$ on $\mathrm{HO}_{\mathrm{x}}$ during Arctic spring}

Halogen chemistry can potentially impact $\mathrm{HO}_{\mathrm{x}}$ by altering (decreasing) the $\mathrm{HO}_{2} / \mathrm{OH}$ ratio, and also by increasing the total source of $\mathrm{HO}_{\mathrm{x}}$. $\mathrm{BrO}$ is formed during the brominedriven catalytic destruction of $\mathrm{O}_{3}$ which has been observed over the Arctic (Oltmans and Komhyr, 1986; Barrie et al., 1988). BrO converts $\mathrm{HO}_{2}$ (and other organic peroxy radicals) to $\mathrm{OH}$ via production of $\mathrm{HOBr}$ followed by its photolysis 

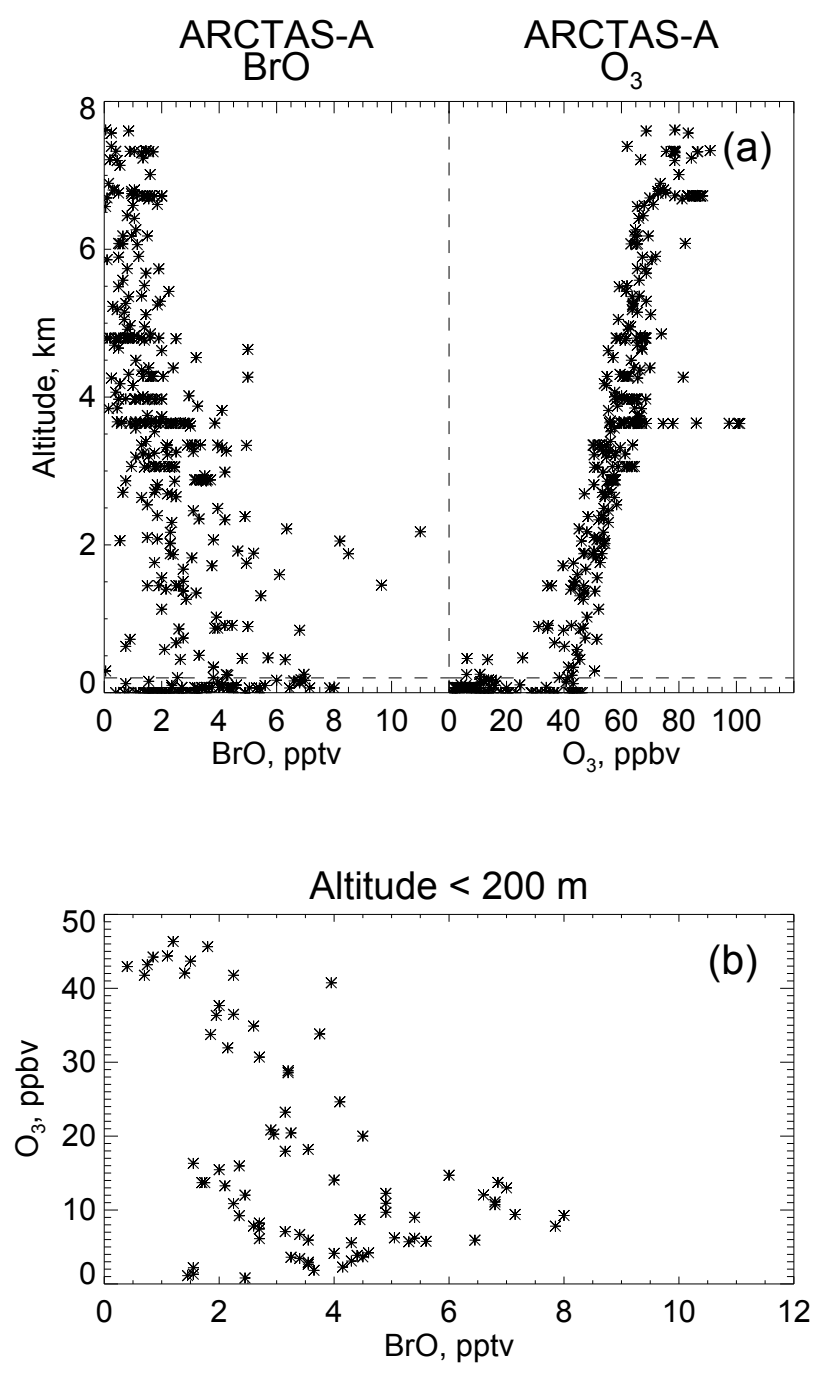

Fig. 13. Observations of $\mathrm{BrO}$ and $\mathrm{O}_{3}$ during ARCTAS-A. Panel (a) shows observed altitude profiles of $\mathrm{BrO}$ and $\mathrm{O}_{3}$ and (b) shows the correlation between $\mathrm{BrO}$ and $\mathrm{O}_{3}$ in the lowest $200 \mathrm{~m}$.

(reactions from Table 1):

$$
\begin{aligned}
& \mathrm{BrO}+\mathrm{HO}_{2} \rightarrow \mathrm{HOBr}+\mathrm{O}_{2} \\
& \mathrm{BrO}+\mathrm{CH}_{3} \mathrm{O}_{2} \rightarrow .25\left(\mathrm{CH}_{2} \mathrm{O}+\mathrm{HO}_{2}+\mathrm{O}_{3}\right) \\
& \quad+.75\left(\mathrm{HOBr}+\mathrm{CH}_{2} \mathrm{O}_{2}\right) \\
& \mathrm{HOBr}+h v \rightarrow \mathrm{Br}+\mathrm{OH}
\end{aligned}
$$

In addition to this halogen impact of decreasing the $\mathrm{HO}_{2} / \mathrm{OH}$ ratio, the reaction of $\mathrm{Br}$ with $\mathrm{CH}_{2} \mathrm{O}$ and other aldehydes can serve as a source of $\mathrm{HO}_{\mathrm{x}}$, e.g.,

$$
\mathrm{Br}+\mathrm{CH}_{2} \mathrm{O} \rightarrow \mathrm{HBr}+\mathrm{CO}+\mathrm{HO}_{2}
$$

For most of the ARCTAS data, the source of $\mathrm{HO}_{\mathrm{x}}$ from (R2) contributes less than $10 \%$ to the total $\mathrm{HO}_{\mathrm{x}}$ source.
However, under conditions where the primary source of $\mathrm{HO}_{\mathrm{x}}$ is sufficiently inhibited due to depleted $\mathrm{O}_{3}$, this bromineinitiated $\mathrm{HO}_{\mathrm{x}}$ source can become significant in the relative sense. Additionally, in the presence of high NO ( $>$ several hundred pptv) elevated concentrations of the bromine radical $(\mathrm{Br})$ are produced by Reaction (R12) such that the $\mathrm{HO}_{2}$ source from (R2) can exceed other photochemical $\mathrm{HO}_{\mathrm{x}}$ sources:

$\mathrm{BrO}+\mathrm{NO} \rightarrow \mathrm{Br}+\mathrm{NO}_{2}$

One of the goals of ARCTAS was to identify observational evidence of these halogen driven impacts on hydrogen radical chemistry. Of the modeled ARCTAS-A data considered in this study, two flights included $\mathrm{BrO}$ measurements (423 modeled points), using a CIMS instrument (Neumann et al., 2010). During ARCTAS, the BrO LOD varied but was generally less than $2 \mathrm{pptv}$. BrO concentrations ranged from up to 8 pptv at the surface to values at LOD in the free troposphere (left panel of Fig. 13a). The right panel in Fig. 13a shows coincident measurements of $\mathrm{O}_{3}$, and verifies that the aircraft sampling captured some incidences of depleted boundary layer $\mathrm{O}_{3}$ likely associated with $\mathrm{BrO}$. While the data are influenced by time of day and varying $\mathrm{NO}_{\mathrm{x}}$ levels, there is some indication of a general decrease of surface level $\mathrm{O}_{3}$ with increasing $\mathrm{BrO}$ for measurements below $200 \mathrm{~m}$ (Fig. 13b).

In its standard configuration, the LaRC steady state model is constrained to measurements of $\mathrm{BrO}$ when measurements are available; this approach assumes equilibrium between the active bromine gas-phase species based on the instantaneous value for BrO. Therefore the availability of this measurement allows an estimation of the instantaneous impact of bromine radicals on gas-phase chemistry without the requirement of including details of aqueous-phase processing and bromine activation in the model (e.g., see Liao et al., 2011). Model results including and then neglecting the measurements of $\mathrm{BrO}$ are compared to predict the instantaneous impact of bromine on the $\mathrm{HO}_{\mathrm{x}}$ budget and cycling in this high latitude environment.

Points with $\mathrm{NO}>200$ pptv or with $\mathrm{O}_{3}$ undergoing depletion events $(<15 \mathrm{ppbv})$ are identified as events that may experience a substantial relative increase in $\mathrm{HO}_{\mathrm{x}}$ source due to reaction of $\mathrm{Br}$ with aldehydes, e.g., Reaction (R2). The remaining background points encompass more than $85 \%$ of the data. The median relative increase in predicted $\mathrm{OH}$ for these background points due to bromine chemistry is $21 \%$ (a $39 \%$ increase for points below $2 \mathrm{~km}$ and a $12 \%$ increase in the middle troposphere). However, this translates into very modest absolute concentration increases of $<0.01 \mathrm{pptv}$ (maximum increase is $0.03 \mathrm{pptv}$ ). As described in Sect. 4.3.1, available measurements of $\mathrm{OH}$ are not sufficient to verify this small impact on $\mathrm{OH}$. The accompanying predicted decrease in background $\mathrm{HO}_{2}$ due to the halogen chemistry impact on $\mathrm{HO}_{2} / \mathrm{OH}$ described above is $\sim 4 \%(0.22 \mathrm{pptv})$. This value is significantly less than the total difference between observations and predictions; e.g., for this subset of points, 

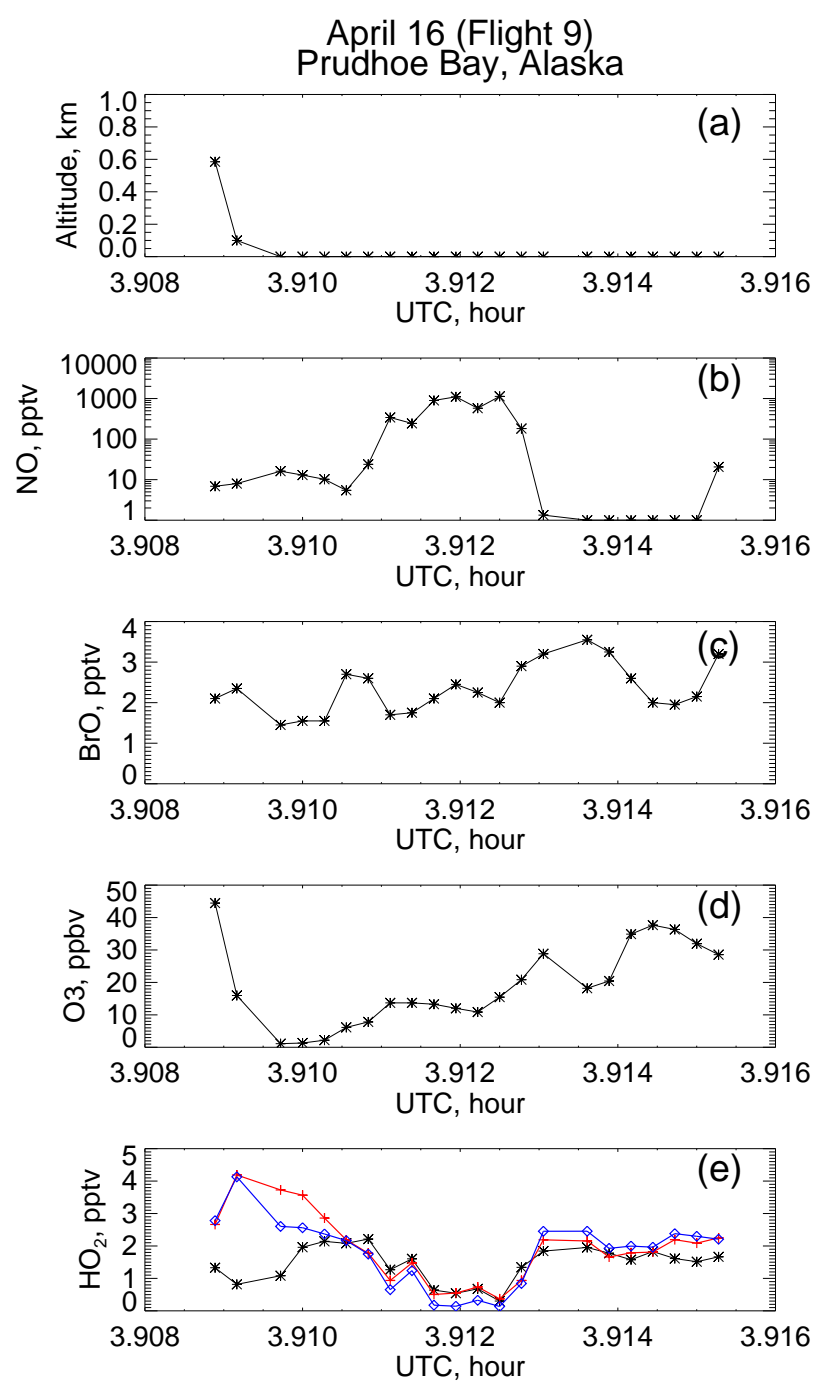

Fig. 14. Case study for impact of bromine on 16 April. Observed time series are shown for (a) Altitude, (b) $\mathrm{NO}$, (c) $\mathrm{BrO}$, and (d) $\mathrm{O}_{3}$. Observations of $\mathrm{HO}_{2}$ are shown in panel (e) along with model predictions of $\mathrm{HO}_{2}$ with and without $\mathrm{BrO}$ chemistry.

the median R-Obs/Calc $\left(\mathrm{HO}_{2}\right)$ improves from 1.69 to 1.61 when $\mathrm{BrO}$ is included in the model calculations. For comparison, Liao et al. (2011) predicted 10-12\% increases in $\mathrm{OH}$ due to bromine chemistry over Summit, Greenland during the spring $2007 \mathrm{GSHO}_{\mathrm{x}}$ (Greenland Summit Halogen- $\mathrm{HO}_{\mathrm{x}}$ ) campaign and 8-10\% decreases in $\mathrm{HO}_{2}+\mathrm{RO}_{2}$.

For the 15 points identified as likely $\mathrm{HO}_{\mathrm{x}}$ source events due to pollution $(\mathrm{NO}>200 \mathrm{pptv})$, the total $\mathrm{HO}_{\mathrm{x}}$ source increases by a factor of 5 , resulting in increases of $\mathrm{OH}$ and $\mathrm{HO}_{2}$ on the order of 0.03 pptv and 0.4 pptv respectively. For the points with depleted $\mathrm{O}_{3}$ (42 points), the total $\mathrm{HO}_{\mathrm{x}}$ source increases by $68 \%$ as a result of bromine chemistry, resulting in an $\mathrm{OH}$ increase of $0.01 \mathrm{pptv}$ and $\mathrm{HO}_{2}$ increase of 0.36 pptv.
Figure 14 is a case study time series of data from 16 April during a very low altitude leg over Prudhoe Bay to illustrate the various impacts of bromine chemistry on the predictions of $\mathrm{HO}_{2}$ for different chemical environments. Altitude is shown in Fig. 14a, with observations of $\mathrm{NO}, \mathrm{BrO}$ and $\mathrm{O}_{3}$ in Fig. 14b-d. The ATHOS measurements of $\mathrm{HO}_{2}$ for this flight leg are shown in Fig. 14e (black), along with model predictions of $\mathrm{HO}_{2}$ without bromine chemistry (blue) and with bromine chemistry included (red). Potential $\mathrm{HO}_{\mathrm{x}}$ source events are shown at UTC 3.910 (depleted $\mathrm{O}_{3}$ ) and in the vicinity of 3.912 (elevated NO). In each case, the prediction of $\mathrm{HO}_{2}$ is larger when bromine chemistry is included as a result of an increase in the total $\mathrm{HO}_{\mathrm{x}}$ source. The agreement with measurements worsens in the $\mathrm{O}_{3}$ depletion case, but improves to excellent agreement in the high NO case. Background conditions are shown in the vicinity 3.914, where NO drops to less than $10 \mathrm{pptv}$, and $\mathrm{O}_{3}$ remains at concentrations $>20$ ppbv In this case, predicted $\mathrm{HO}_{2}$ decreases with the addition of bromine chemistry as a result of the halogen driven decrease of the $\mathrm{HO}_{2} / \mathrm{OH}$ ratio, improving the agreement between model and observed $\mathrm{HO}_{2}$.

While there were no measurements of iodine radicals available during ARCTAS, there is recent observational evidence of the presence of IO over isolated regions in the Arctic regions of up to a few pptv (Mahajan et al., 2010). That study suggested that at those concentrations, IO will deplete $\mathrm{O}_{3}$ at rate comparable to $\mathrm{BrO}$, as well as enhance the effect of bromine-catalyzed $\mathrm{O}_{3}$ depletion. Modeling studies have indicated that iodine chemistry is also expected to have a significant impact on the $\mathrm{HO}_{2} / \mathrm{OH}$ ratio, parallel to that from $\mathrm{BrO}$ (Bloss et al., 2005; Saiz-Lopez et al., 2011).

\subsection{4 $\mathrm{HO}_{2}$}

A systematic model over prediction of $\mathrm{HO}_{2}$ was shown in Fig. 8 and Tables 5 and 6 . Figure 15a shows that the RObs/Calc $\left(\mathrm{HO}_{2}\right)$ is correlated with temperature not only through the two high latitude ARCTAS phases, but also through the portions of the ARCTAS-CARB phase that reached low temperatures (shown in green). The absolute difference between observations and predictions of $\mathrm{HO}_{2}$ for all three phases are shown in Fig. 15b. For temperatures below $260 \mathrm{~K}$, there is a persistent bias of about $2.5 \mathrm{pptv}$ during ARCTAS-A, and of 5 pptv during ARCTAS-B and ARCTAS-CARB. Stratospheric points for all three phases are shown in the figures with the black plus symbols. There does not appear to be any marked difference in the observation to model comparison for the stratospheric points relative to the tropospheric points. Similar to these box model results, Mao et al. (2010) found an over prediction of $\mathrm{HO}_{2}$ when comparing results from the chemical transport model GEOS-Chem to ATHOS measurements during ARCTAS-A, and speculated that a temperature-dependent aerosol loss of $\mathrm{HO}_{2}$ could provide a sufficient additional sink to reconcile $\mathrm{HO}_{2}$ measurements and theory. The loss of $\mathrm{HO}_{2}$ to aerosol 

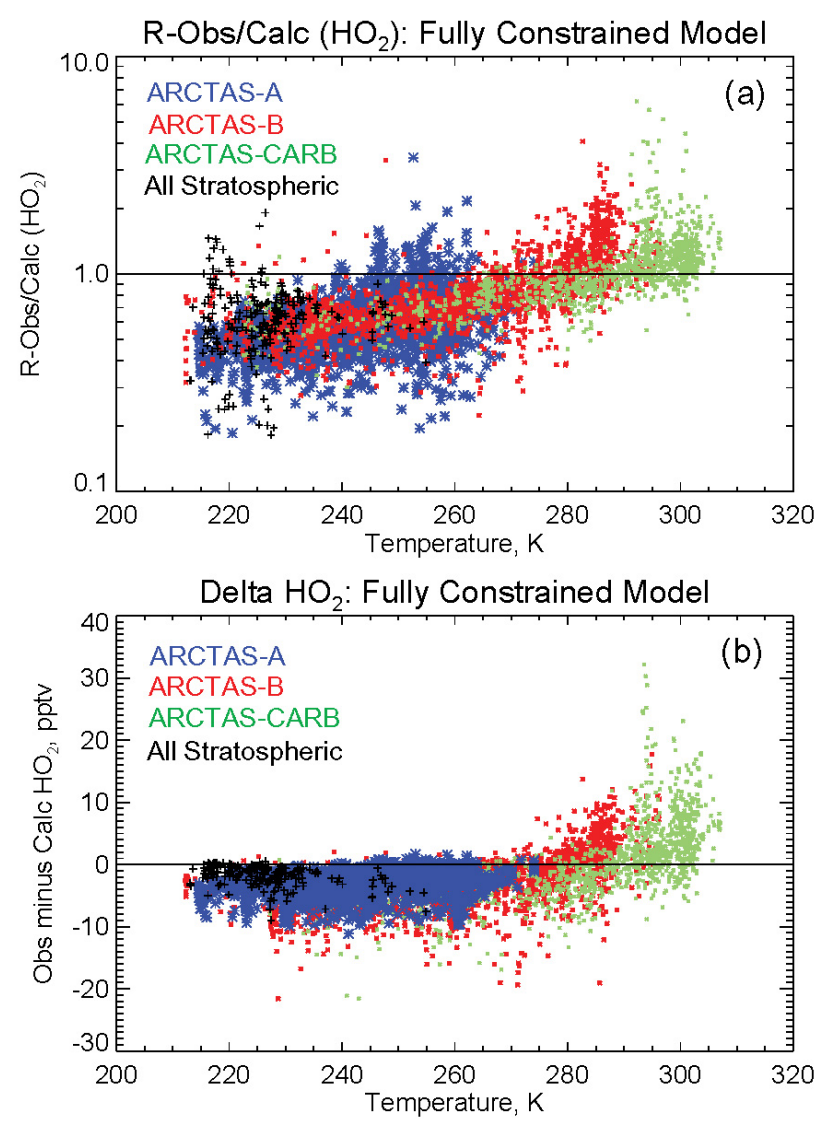

Fig. 15. Model predicted and observation comparisons for $\mathrm{HO}_{2}$ as a function of temperature. Panel (a) shows R-Obs/Calc $\left(\mathrm{HO}_{2}\right)$ for ARCTAS-A, -B and -CARB and (b) shows the difference between observations and model predictions for $\mathrm{HO}_{2}$ as a function of temperature.

was proposed to proceed as a pseudo first-order loss rate, dependent upon the surface area of the aerosol and a reaction probability that is highly sensitive to temperature and based largely on Thornton et al. (2008). Additionally, Mao et al. (2010) proposed a novel aqueous phase chemistry process that bypasses the formation of $\mathrm{H}_{2} \mathrm{O}_{2}$, thus rendering the aerosol reaction a terminal loss of $\mathrm{HO}_{y}$.

The results from Mao et al. (2010) are based on threedimensional model predictions of physical parameters and chemical precursor fields, and are useful for assessing relative influences on the chemical system as a whole. However, the $\mathrm{HO}_{\mathrm{x}}$ precursor fields generated by global models are not sufficient to perform a direct measurement-to-model assessment of $\mathrm{HO}_{\mathrm{x}}$. The only way to determine whether a terminal loss of $\mathrm{HO}_{2}$ to aerosol is sufficient to reconcile insitu observations of $\mathrm{HO}_{\mathrm{x}}$ with theory is to directly consider the observed precursor fields. Measurements of $\mathrm{HO}_{\mathrm{x}}$, its precursors, and species and parameters impacting its loss (i.e., aerosol surface area and temperature) are used here with the observationally constrained box model to examine the proposed temperature-dependent heterogeneous loss of $\mathrm{HO}_{2}$. The loss rate is calculated using an aerosol surface area density $(\mathrm{SAD})$ and a reaction probability $(\gamma)$ :

$\mathrm{HO}_{2}$ loss rate $=\frac{\mathrm{SAD}}{\left\{\frac{4}{\gamma \omega}+\frac{r_{\mathrm{p}}}{D_{\mathrm{g}}}\right\}}$

where $\omega$ is the temperature-dependent mean molecular speed of $\mathrm{HO}_{2}, r_{\mathrm{p}}$ is the particle radius, and $D_{\mathrm{g}}$ is the diffusion coefficient for $\mathrm{HO}_{2}$. Unfortunately, measurements of aerosol SAD from the DC- 8 are not available for altitudes above about $3 \mathrm{~km}$ during ARCTAS because the Ultra High Sensitivity Aerosol Spectrometer instrument was not functional above this altitude. Measurements of aerosol scattering @ $550 \mathrm{~nm}$ were available on the DC-8, however, and are used here as a proxy to estimate aerosol SAD. The relationship between SAD and aerosol scattering@550 nm can be obtained for altitudes up to $8 \mathrm{~km}$ during ARCTAS using measurements from the suite of instruments on board the P3-B aircraft (operated by the Hawaii Group for Environmental Aerosol Research; Clark, 1991); this relationship is then applied to observations of aerosol scattering @ 550 nm obtained from the DC-8 to obtain estimates of SAD values consistent with the DC-8 data set.

The aerosol SAD measurements from the P3-B are shown in Fig. 16a and $\mathrm{b}$ in blue. Below $4 \mathrm{~km}$, local fire emissions result in very high aerosol SAD values (off scale in Fig. 16b) but as will be shown, a heterogeneous loss to aerosol at the lower altitudes has little impact on $\mathrm{HO}_{2}$ due to the magnitude of competing gas phase losses of $\mathrm{HO}_{\mathrm{x}}$ at these altitudes. Note that these values for aerosol SAD assume dry particles, and therefore have an uncertainty associated with them in the presence of sufficient relative humidity $(\mathrm{RH})$. For these P3-B data, 3/4 of the points above $6 \mathrm{~km}$ are at less than $56 \%$ RH. For these dry conditions, the uncertainty in SAD is likely less than about a factor of 2 . Figure $16 \mathrm{c}$ and $\mathrm{d}$ show the linear fits obtained using the correlation for SAD values $<30 \mathrm{~cm}^{2} \mathrm{~cm}^{-3}$ and aerosol scattering @ 550 nm using measurements from the P3-B. Resulting estimates for SAD for the DC- 8 using that linear fit applied to DC- 8 measurements of aerosol scattering @ 550 are indicated with the white bars in Fig. 16a and b. Aerosol SAD estimates for the DC-8 are similar to those from the P3-B in both median and range. For comparison, the predicted aerosol SAD from the GEOSChem global model for the same subset of DC- 8 points is also shown in the figure (gray bars), with median values up to a factor of $\sim 2$ larger than those from the airborne measurements. Given the uncertainty related to $\mathrm{RH}$, the difference between the estimates from in-situ data and those from GEOS-Chem can be interpreted as a reasonable range of values for SAD in the high latitude upper troposphere.

To estimate values for the reaction probability $(\gamma)$ for the $\mathrm{HO}_{2}$ aerosol loss in Eq. (1), a temperature-dependent estimate is based on that described in Thornton et al. (2008), assuming a $\mathrm{pH}$ of 5 and a particle radius of $0.2 \mu \mathrm{m}$. The 

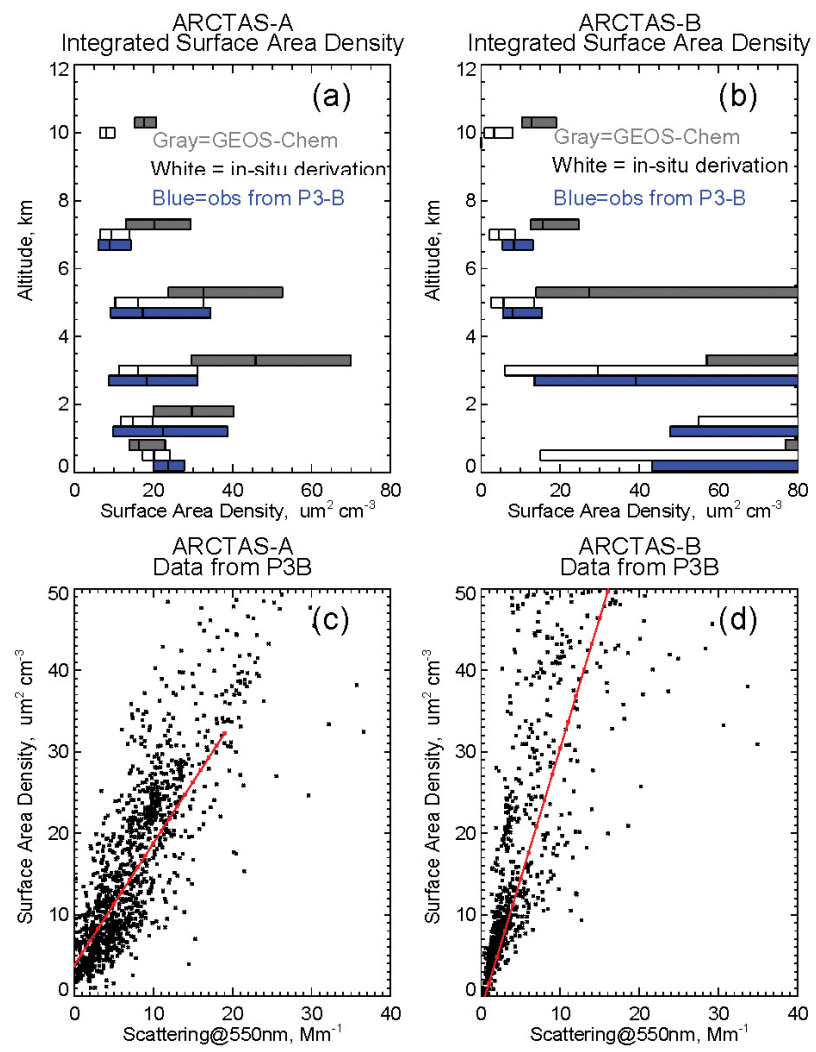

Fig. 16. Integrated surface area density (SAD) and scattering @ 550 nm during ARCTAS. Altitude profiles of SAD are shown for (a) ARCTAS-A and (b) ARCTAS-B. Bars show values of SAD obtained from $\mathrm{P} 3-\mathrm{B}$ observations, from derivations using a correlation to DC-8 observations of scattering @ $550 \mathrm{~nm}$, and from calculations using the GEOS-Chem model. Bar plots are as described in Fig. 2. The correlation between measurements of SAD and scattering @ $550 \mathrm{~nm}$ from the P3-B are shown for (c) ARCTAS-A and (d) ARCTAS-B.

calculated reaction probability ranges from 0.06 near the surface to 0.7 in the upper troposphere. The assumption of a particle radius $\left(r_{\mathrm{p}}\right)=0.2 \mu \mathrm{m}$ in Eq. (1) will overestimate the loss rate when larger particles dominate; P3-B size distribution data suggest that above $6 \mathrm{~km}, \sim 60 \%$ of the integrated surface area is from particles $<.2 \mu \mathrm{m}$ radius, on average. This in-situ based estimate of the terminal aerosol loss for $\mathrm{HO}_{2}$ is shown in Fig. 17a and b (white bars) along with the corresponding loss calculated by GEOS-Chem along the DC-8 flight tracks (gray bars). The GEOS-Chem calculation employs a similar approach to that used here, but integrates throughout the full spectrum of the model-generated particle size distribution information. The two estimates for the $\mathrm{HO}_{2}$ loss rate to aerosol are generally consistent, with that predicted by GEOS-Chem somewhat larger, particularly during summer, driven by the larger SAD in GEOS-Chem. For the fully constrained box model test used here, this aerosol loss for $\mathrm{HO}_{2}$ will only be effective at decreasing concen-
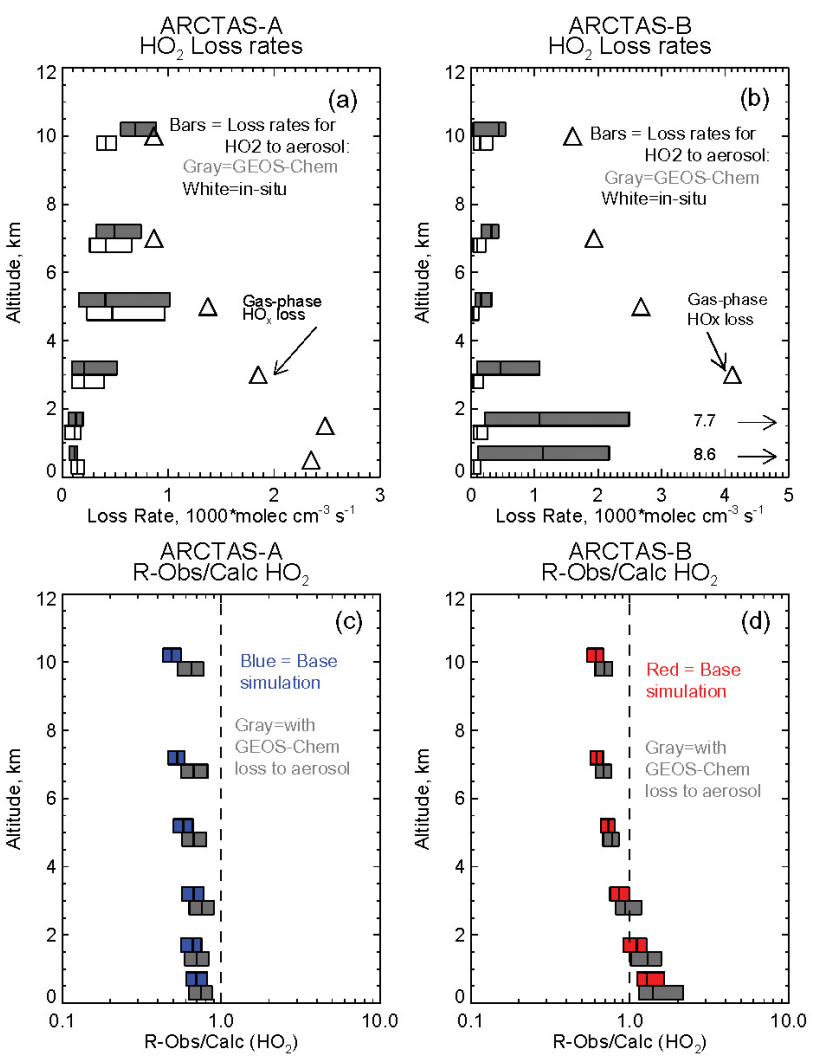

Fig. 17. Impact of including a heterogeneous loss rate of $\mathrm{HO}_{2}$ to aerosol on predictions of $\mathrm{HO}_{2}$. Altitude profiles of the loss rate of $\mathrm{HO}_{2}$ to aerosol calculated in GEOS-Chem and from using in-situ observations are shown for (a) ARCTAS-A and (b) ARCTAS-B. Predictions of the gas-phase loss of $\mathrm{HO}_{2}$ using the LaRC box model and in-situ observations are shown for comparison. Altitude profiles of the observed-to-calculated ratios of $\mathrm{HO}_{2}$ from simulations that do and do not include the heterogeneous loss of $\mathrm{HO}_{2}$ to aerosol are shown for (c) ARCTAS-A and (d) ARCTAS-B.

trations of $\mathrm{HO}_{2}$ if the magnitude of the estimated loss rate is competitive with the gas phase losses of $\mathrm{HO}_{\mathrm{x}}$, shown by the open triangles in Fig. 17a and b (including the $\mathrm{HO}_{2}$ self reaction, reaction of $\mathrm{HO}_{2}$ with $\mathrm{RO}_{2}$ to form organic peroxides, and reaction of $\mathrm{OH}$ with $\mathrm{NO}_{2}$ to form $\mathrm{HNO}_{3}$ ). For altitudes near the surface, the gas phase losses clearly dominate the estimates for aerosol loss. In the upper troposphere, the aerosol loss approaches values of the gas-phase loss during ARCTAS-A, and reaches 20 to $30 \%$ of the gas-phase loss during ARCTAS-B.

To test the impact of including this $\mathrm{HO}_{2}$ loss to aerosol using the observationally constrained box model, the larger loss rates from GEOS-Chem are adopted to give an upper bound estimate of the $\mathrm{HO}_{2}$ loss. The loss rate is assumed to be terminal, as in Mao et al. (2010). The resulting changes in the R-Obs/Calc $\mathrm{HO}_{2}$ ratio are shown in Fig. $17 \mathrm{c}$ and d, where the blue (ARCTAS-A) and red (ARCTAS-B) bars show the standard model results, and the gray bars show results when the 
$\mathrm{HO}_{2}$ loss to aerosol adopted from GEOS-Chem is included. In the upper troposphere for ARCTAS-A, the predicted $\mathrm{HO}_{2}$ concentration decreases by $\sim 23 \%$ as a result of the loss to aerosol, though it is clearly not sufficient to reconcile the discrepancy with observations. Differences in the absolute concentrations of $\mathrm{HO}_{2}$ predicted here and those by GEOS-Chem in Mao et al. (2010) stem from distributions of $\mathrm{CH}_{2} \mathrm{O}, \mathrm{H}_{2} \mathrm{O}_{2}$, $\mathrm{H}_{2} \mathrm{O}$ and $\mathrm{J}\left(\mathrm{O}^{1} \mathrm{D}\right)$ that are lower in GEOS-Chem than were observed during ARCTAS. The impact during ARCTAS-B is more subdued as expected, due to the relatively larger competing gas-phase $\mathrm{HO}_{\mathrm{x}}$ losses. In both phases, a significant bias toward over prediction remains, particularly at upper altitudes, with the median R-Obs/Calc $\left(\mathrm{HO}_{2}\right)$ above $4 \mathrm{~km}$ equal to 0.66 during ARCTAS-A and equal to 0.72 during ARCTAS-B. The $\mathrm{HO}_{2}$ loss to aerosol in the upper troposphere would need to be three times larger than those adopted from GEOS-Chem during ARCTAS-A and six times larger during ARCTAS-B in order to predict $\mathrm{HO}_{2}$ at the approximate magnitude of observations. Because the reaction probabilities at the high altitude colder temperatures are already large, this would suggest that the increases would need to come largely from higher values of aerosol SAD. Because GEOS-Chem values of SAD used in this calculation of the loss rate are approximately twice as large as the dry-particle in-situ derivations, this would in turn imply that values of SAD would be required to be 6 to 12 times larger than the insitubased estimate. Increases of this order of magnitude are generally outside of the range of uncertainty associated with measurements for this region.

\subsubsection{Coupling $\mathrm{HO}_{\mathrm{x}}$ and $\mathrm{HO}_{\mathrm{x}}$ precursors}

Figures 18 and 19 show predictions of $\mathrm{HO}_{2}, \mathrm{OH}, \mathrm{CH}_{2} \mathrm{O}$ and $\mathrm{H}_{2} \mathrm{O}_{2}$ from a suite of model simulations. The standard fully constrained model simulation (heavy solid line), and that including the loss of $\mathrm{HO}_{2}$ to aerosol (heavy dash-dot line) have been discussed previously. The figures also show several additional partially unconstrained simulations that test the ability of model photochemistry to sustain observed values of $\mathrm{HO}_{\mathrm{x}}$ reservoir precursors (peroxides and $\mathrm{CH}_{2} \mathrm{O}$ ) by predicting one or more of those species from model photochemistry rather than constraining to observations. Predictions of peroxides are highly sensitive to the model assumptions for rainout and deposition loss; within the lowest $\mathrm{km}$ the $\mathrm{H}_{2} \mathrm{O}_{2}$ lifetime due to surface deposition dominates its near-surface total loss rate, and up to $4 \mathrm{~km}$ the assumed rainout lifetime is approximately equal to the photochemical lifetime for $\mathrm{H}_{2} \mathrm{O}_{2}$. Because the history of physical loss due to rainout and/or deposition for any given air mass is highly uncertain, additional model simulations are performed that neglect surface deposition and rainout loss (dry simulations) in order to provide a range of predictions that bracket likely scenarios for these losses. The figures also show median observed values from ARCTAS with $\pm 2 \sigma$ instrument uncertainties (asterisks and horizontal lines), and median observations from TOPSE-sp are shown with the open triangles in Fig. 18 for comparison to ARCTAS-A.

The collective group of model predictions shows a persistent over prediction of $\mathrm{HO}_{2}$ during both seasons. For both ARCTAS-A and - $\mathrm{B}$, the prediction of $\mathrm{HO}_{2}$ that is most consistent with observations comes from a dual unconstrained model simulation (thin black line), in which both peroxides and $\mathrm{CH}_{2} \mathrm{O}$ are predicted from steady state. Above the boundary layer, predictions of $\mathrm{HO}_{2}$ from this simulation are 30 $40 \%$ lower than those from the standard fully constrained run during ARCTAS-A, and they are 10-25\% lower during ARCTAS-B. However, the predictions of $\mathrm{H}_{2} \mathrm{O}_{2}$ and $\mathrm{CH}_{2} \mathrm{O}$ from this simulation (thin black lines in Figs. 18c, d and 19c, d) are well below ARCTAS observations, emphasizing the inconsistency between measurements of $\mathrm{HO}_{\mathrm{x}}$ and of its precursors during ARCTAS. The predictions of $\mathrm{H}_{2} \mathrm{O}_{2}$ during ARCTAS-A are of similar magnitude to those measured during TOPSE-sp, and it can be argued that both lie just within the range of ARCTAS $\mathrm{H}_{2} \mathrm{O}_{2}$ instrument $2 \sigma$ uncertainty. Whether differences are within or outside of the range of measurement uncertainty, however, it is clear that these differences in predicted and measured $\mathrm{HO}_{\mathrm{x}}$ precursor concentrations have important implications for the $\mathrm{HO}_{\mathrm{x}}$ budget.

As discussed previously, predictions of $\mathrm{OH}$ during ARCTAS-A are consistent with observations in the median, but there is a clear under prediction of $\mathrm{OH}$ during ARCTAS$\mathrm{B}$ for all but the highest altitudes (Figs. 18b and 19b). The blue thin dotted line in Fig. 19b shows $\mathrm{OH}$ predictions for ARCTAS-B from the sensitivity run using the fully constrained standard model where NO was universally increased by its $2 \sigma$ uncertainty of $16 \mathrm{pptv}$ (discussed in Sect. 4.3.2). This sensitivity run reproduces median observed $\mathrm{OH}$ concentrations in the middle and lower troposphere, while changes to $\mathrm{HO}_{2}$ are minor (less than a few percent). This emphasizes the sensitivity of $\mathrm{OH}$ predictions to uncertainties in the $\mathrm{NO}$ measurement during ARCTAS.

Simulations were also run whereby the constraint of a single $\mathrm{HO}_{\mathrm{x}}$ precursor is individually relaxed; i.e., peroxides are constrained to observations while $\mathrm{CH}_{2} \mathrm{O}$ is predicted (green lines, see Figs. $18 \mathrm{~d}$ and $19 \mathrm{~d}$ ) and $\mathrm{CH}_{2} \mathrm{O}$ is constrained to observations while peroxides are predicted (purple lines, see Figs. 18c and 19c). The corresponding dashed green and purple lines show results from the dry simulations, whereby the rainout loss for the predicted precursor is neglected. In general, the impact on $\mathrm{CH}_{2} \mathrm{O}$ predictions due to peroxide constraint is small. Predictions increase and are closer to observations above $8 \mathrm{~km}$ during ARCTAS-A and below $4 \mathrm{~km}$ during ARCTAS-B, however $\mathrm{CH}_{2} \mathrm{O}$ predictions remain significantly lower than observations throughout most of the free troposphere during both phases, part (Figs. 18d and 19d). Alternately, when $\mathrm{CH}_{2} \mathrm{O}$ is held constrained to observed values, the predicted $\mathrm{H}_{2} \mathrm{O}_{2}$ from the rainout and the dry simulations bracket observations for all but the very highest altitudes $(>8 \mathrm{~km})$ during both phases. Thus, while the model is unable to reproduce any consistency between observed 


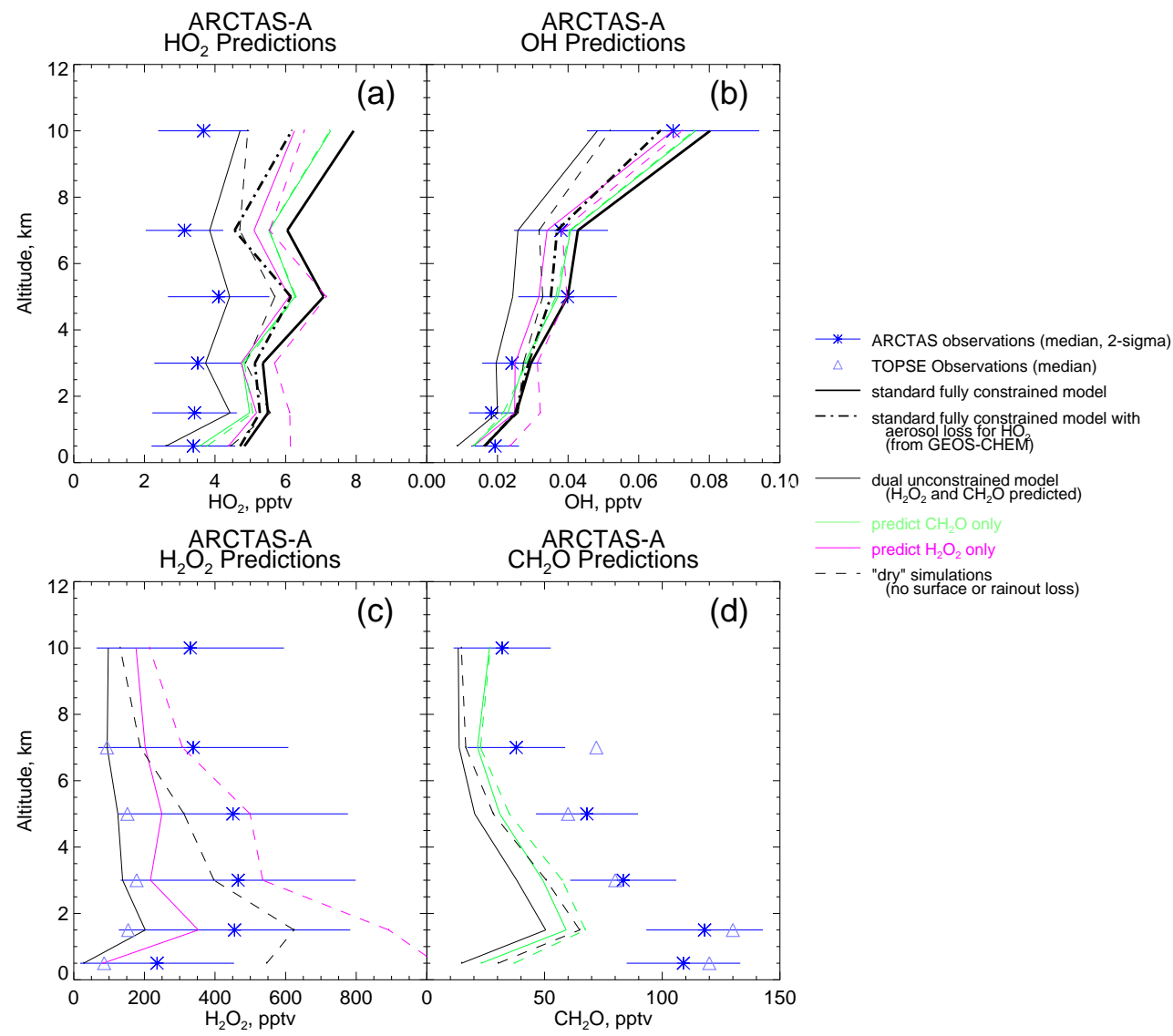

Fig. 18. Altitude profiles for observations and model predictions of (a) $\mathrm{HO}_{2}$, (b) $\mathrm{OH}$, (c) $\mathrm{H}_{2} \mathrm{O}_{2}$ and (d) $\mathrm{CH}_{2} \mathrm{O}$ during ARCTAS-A, with model predictions from several different permutations of the LaRC box model. Asterisks show the median observations, and the associated horizontal blue lines indicate the $2 \sigma$ uncertainty in the observation. Median observations of $\mathrm{H}_{2} \mathrm{O}_{2}$ and $\mathrm{CH}_{2} \mathrm{O}$ from TOPSE-sp are shown with triangles in (c) and (d).

concentrations of $\mathrm{HO}_{\mathrm{x}}$ and of its precursors, it is possible to argue there is some consistency between measurements of $\mathrm{CH}_{2} \mathrm{O}$ and $\mathrm{H}_{2} \mathrm{O}_{2}$ when $\mathrm{CH}_{2} \mathrm{O}$ is forced to observations.

Observed levels of $\mathrm{CH}_{2} \mathrm{O}$ cannot be explained by model photochemical theory, and the diurnally averaged lifetime of $\mathrm{CH}_{2} \mathrm{O}$ is short enough to preclude a significant source from middle latitude transport (6-10 $\mathrm{h}$ during ARCTAS-A and 3$10 \mathrm{~h}$ during ARCTAS-B). Sources that are not included in the box model such as emission from the snowpack and/or direct emission from fires may explain a portion of the model under predictions at the lowest altitudes, but these surface sources are unlikely to have a persistent impact throughout the extent of the troposphere during ARCTAS-A. The instances of convection observed during ARCTAS-B are a likely mechanism for transport of surface levels of $\mathrm{CH}_{2} \mathrm{O}$ into the upper troposphere. In addition, convective transport of very short lived precursors such as isoprene can have an impact on upper tropospheric $\mathrm{CH}_{2} \mathrm{O}$ concentrations that persist beyond the observable levels of the precursors; however the model under predictions of $\mathrm{CH}_{2} \mathrm{O}$ are persistent and not limited to convective events. Fried et al. (2003) suggested that a temperature-dependent branching of $\mathrm{CH}_{3} \mathrm{O}_{2}+\mathrm{HO}_{2}$ to directly produce $\mathrm{CH}_{2} \mathrm{O}$ may be important in cold temperatures (Elrod et al., 2001). This branching ratio varies from $10-15 \%$ at the surface to $25 \%$ in the upper troposphere for ARCTAS conditions. However including this branch in the model chemistry did not substantially change predicted concentrations of $\mathrm{CH}_{2} \mathrm{O}$.

Figure 20 shows that model predictions of acetaldehyde $\left(\mathrm{CH}_{3} \mathrm{CHO}\right)$ during ARCTAS are lower than both of two independent measurements using the PTRMS and TOGA instruments. To investigate the magnitude of an additional photochemical source of $\mathrm{CH}_{2} \mathrm{O}$ from oxidation of observed levels of acetaldehyde, the model is run in a mode to predict $\mathrm{CH}_{2} \mathrm{O}$ while retaining all other constraints with the additional constraint of acetaldehyde. The higher values of $\mathrm{CH}_{3} \mathrm{CHO}$ from PTRMS are used to give upper bound estimates. Predicted $\mathrm{CH}_{2} \mathrm{O}$ increases by less than 3 pptv during ARCTAS-A, except for altitudes $>8 \mathrm{~km}$, where predicted $\mathrm{CH}_{2} \mathrm{O}$ increases by $7.5 \mathrm{pptv}$ to explain approximately half of the discrepancy 


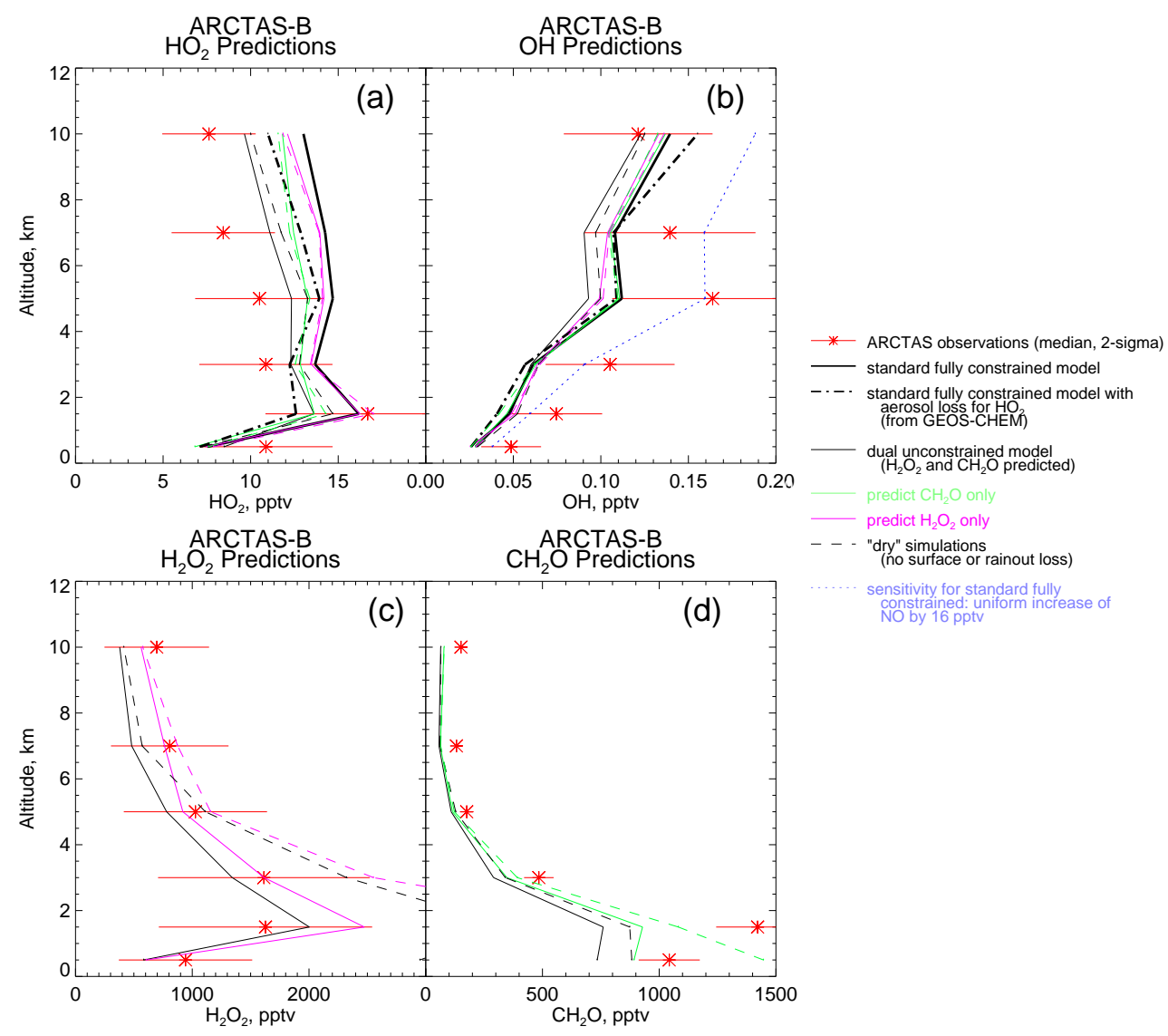

Fig. 19. As in Fig. 18, but for ARCTAS-B.

between the model and observations. During ARCTAS-B, predicted $\mathrm{CH}_{2} \mathrm{O}$ increases by $20 \mathrm{pptv}$ for altitudes above $2 \mathrm{~km}$, explaining between $25-60 \%$ of the discrepancy.

The estimate of an additional flux of $\mathrm{CH}_{3} \mathrm{CHO}$ required to reproduce the larger observations measured by PTRMS ranges from 35-90 pptv day ${ }^{-1}$ during ARCTAS-A, and up to several hundred pptv day ${ }^{-1}$ during ARCTAS-B. While the lifetime of acetaldehyde is longer than that of formaldehyde (1-3 days during spring and $\sim 1$ day during summer), it is not long enough to support a sustained significant transport flux of this magnitude. Kwan et al. (2006) speculate that oxidation of organic aerosols could be a source of oxygenated volatile organic compounds (OVOCs), and propose that up to 70 pptv $\mathrm{C}_{\text {day }}{ }^{-1}$ (equivalent to 35 pptv day ${ }^{-1} \mathrm{CH}_{3} \mathrm{CHO}$ ) is possible in the upper troposphere over North America. Another possible source of acetaldehyde might be due to oxidation of unmeasured higher hydrocarbons. The origin of such a source that is pervasive throughout the high latitude troposphere is unknown.

\section{$5 \quad O_{3}$ budget}

The diurnally averaged gross photochemical formation and destruction of $\mathrm{O}_{3}$ during the two ARCTAS phases is shown in Fig. 21a and $b$ by the bars on either side of the zero line. For ARCTAS-B, the results shown are limited to the "background" points, described in Sect. 3.2. The median net $\mathrm{O}_{3}$ photochemical tendencies are shown by the blue (ARCTASA) and red (ARCTAS-B) lines. $\mathrm{O}_{3}$ gross formation ranges from 0.4-0.8 ppbv day ${ }^{-1}$ during ARCTAS-A, with the upper value occurring at $1-4 \mathrm{~km}$. This rate is in general agreement with the range of calculations for TOPSE (Cantrell et al., 2003a; Stroud et al., 2004). The net photochemical production of $\mathrm{O}_{3}$ during spring is zero throughout most of the troposphere, with a small net positive production at highest altitudes of $0.2 \mathrm{ppbv} \mathrm{day}^{-1}$. This supports the conclusions of TOPSE, that in order to support the springtime build up of $\mathrm{O}_{3}$ at high latitudes, a combination of both transport of $\mathrm{O}_{3}$ from middle latitudes and gross photochemical production is required. During summer (ARCTAS-B), the background data shows a gross production of $\mathrm{O}_{3}$ in the boundary layer and at the highest altitudes $2-4$ ppbv day $^{-1}$, with a net photochemical production of $1-2 \mathrm{ppbv}$ day $^{-1}$. The middle troposphere 

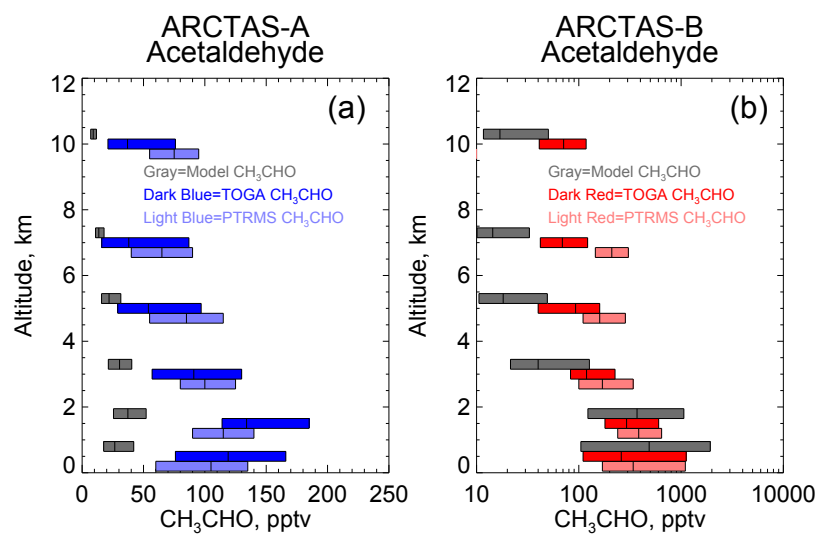

Fig. 20. Altitude profiles of observations and model predictions of acetaldehyde during (a) ARCTAS-A and (b) ARCTAS-B. Bar plots are as described in Fig. 2.

is characterized by net photochemical destruction of about 1 ppbv day $^{-1}$.

Given the persistent model over prediction of $\mathrm{HO}_{2}$, it is instructive to determine if and how much the $\mathrm{O}_{3}$ formation and destruction rates during ARCTAS would vary if observed $\mathrm{HO}_{2}$ were considered, rather than model-calculated values. Figure $21 \mathrm{c}$ and $\mathrm{d}$ show the revised gross production and destruction rates, and the net production calculated using the observed $\mathrm{HO}_{2}$ values. Throughout the free troposphere during both phases and extending to the surface during ARCTAS-A, gross production rates are 25-50\% lower when using observed $\mathrm{HO}_{2}$ (see Table 7). Gross destruction is similarly reduced, so that differences in the net $\mathrm{O}_{3}$ production rate are negligible.

\section{Summary}

Observations obtained during ARCTAS were analyzed using the observationally constrained NASA Langley Research Center photochemical box model in order to assess the tropospheric photochemical cycling occurring over high latitudes and its impact on the $\mathrm{O}_{3}$ budget. At high latitudes and particularly during the spring, low radiation, cold temperatures, and dry conditions suppress photochemistry such that concentrations of many of the radicals and precursor species are very low. The resulting relative uncertainties in measurements and model predictions are sufficiently large so as to preclude a rigorous photochemical assessment.

While model predictions of $\mathrm{OH}$ during the spring (ARCTAS-A) are in general agreement with measurements $(\mathrm{R}-\mathrm{Obs} / \mathrm{Calc}=0.96)$, observations of $\mathrm{OH}$ are frequently at LOD. The low concentrations in the boundary layer and lower troposphere are shown to have observational scatter and model prediction uncertainties that are at the order of magnitude of the ambient concentrations, limiting the usefulness of further observational analysis. Alternately, dur-
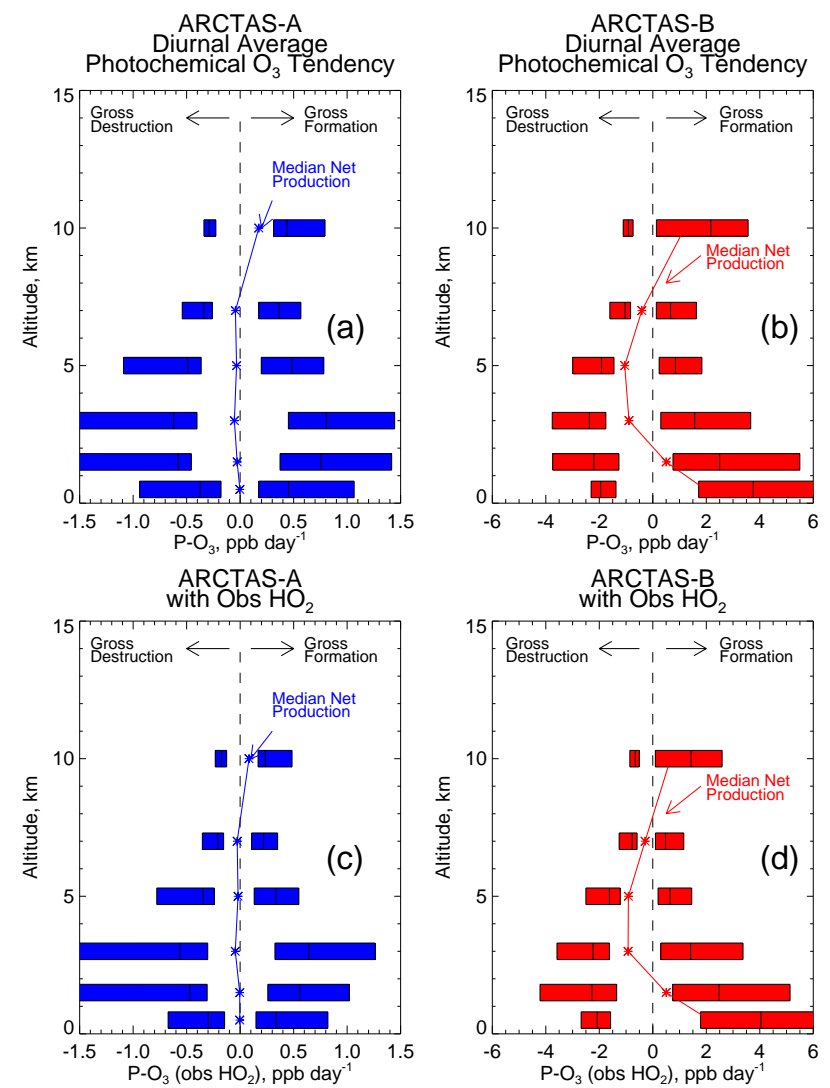

Fig. 21. Altitude profiles of diurnally averaged model calculated gross formation and destruction and net production of $\mathrm{O}_{3}$ during (a) ARCTAS-A and (b) ARCTAS-B. Bar plots are as described in Fig. 2. Panels (c) and (d) are for the diurnally averaged gross formation and destruction and net production of $\mathrm{O}_{3}$ using observed $\mathrm{HO}_{2}$ rather than model predictions.

ing summer (ARCTAS-B), concentrations of $\mathrm{OH}$ are four times larger than during spring, but predictions of $\mathrm{OH}$ are persistently lower than observations for all but the highest $\mathrm{OH}$ concentrations $(\mathrm{R}-\mathrm{Obs} / \mathrm{Calc}=1.25)$. The R-Obs/Calc $\mathrm{HO}_{2} / \mathrm{OH}$ ratio shows a clear trend with $\mathrm{NO}$ with largest over-predictions at low NO concentrations. The uncertainty in model predictions of $\mathrm{OH}$ associated with uncertainties in observational constraints is dominated by the NO measurement uncertainty, and is largest at low values of NO. Predicted $\mathrm{OH}$ is consistent with measurements (within $10 \%$ ) if $\mathrm{NO}$ is increased uniformly within the bounds of its $2 \sigma$ uncertainty, though there is no reason to suspect a bias in NO measurement at this time.

The largest sources of $\mathrm{HO}_{2}$ in the middle and upper troposphere during ARCTAS are photolysis of $\mathrm{H}_{2} \mathrm{O}_{2}$ and $\mathrm{CH}_{2} \mathrm{O}$. Predictions of $\mathrm{HO}_{2}$ are up to a factor of two larger than measurements when $\mathrm{H}_{2} \mathrm{O}_{2}$ and $\mathrm{CH}_{2} \mathrm{O}$ are constrained to their observed values, highlighting the inconsistency between measurements of $\mathrm{HO}_{2}$ and of its reservoir precursor species within the context of the box model mechanism. The 
Table 7. Changes in $\mathrm{O}_{3}$ gross formation when using observed $\mathrm{HO}_{2}$.

\begin{tabular}{lrr}
\hline Altitude & $\begin{array}{r}\text { ARCTAS-A } \\
\text { Percent, } \\
\left(\text { ppbv day }^{-1}\right)\end{array}$ & $\begin{array}{r}\text { ARCTAS-B } \\
\text { Percent, } \\
\left.\text { ppbv day }^{-1}\right)\end{array}$ \\
\hline$>8 \mathrm{~km}$ & $-46 \%(-0.20)$ & $-34 \%(-0.73)$ \\
$6-8 \mathrm{~km}$ & $-40 \%(-0.14)$ & $-28 \%(-0.19)$ \\
$4-6 \mathrm{~km}$ & $-31 \%(-0.15)$ & $-24 \%(-0.20)$ \\
$2-4 \mathrm{~km}$ & $-20 \%(-0.16)$ & $-10 \%(-0.15)$ \\
$1-2 \mathrm{~km}$ & $-26 \%(-0.20)$ & $-0.6 \%(-0.02)$ \\
$0-1 \mathrm{~km}$ & $-26 \%(-0.12)$ & $+7.6 \%(+0.28)$ \\
\hline
\end{tabular}

temperature dependent terminal loss of $\mathrm{HO}_{2}$ to aerosol proposed by Mao et al. (2010) decreased model predictions of $\mathrm{HO}_{2}$ by $\sim 23 \%$ during ARCTAS-A, but was not sufficient to reconcile the differences between measured and predicted $\mathrm{HO}_{2}$.

A comparison of measurements during ARCTAS-A and at high latitudes during the spring portion of the 2000 TOPSE field campaign revealed strikingly consistent measurements of temperature, water vapor, $\mathrm{CO}, \mathrm{NO}, \mathrm{NMHCs}$, and $\mathrm{CH}_{2} \mathrm{O}$. However, differences were apparent in measurements of peroxides, with those during TOPSE several hundred pptv lower than during ARCTAS. A reverse bias is seen for $\mathrm{CH}_{3} \mathrm{OOH}$, with observations during ARCTAS-A 50-70\% lower than during TOPSE. The similarity in physical conditions and photochemical precursors precludes obvious differences in transport, rainout, or in the photochemical budget terms as a cause of the difference. The cause of this difference in peroxides remains unresolved and has important implications for the Arctic $\mathrm{HO}_{\mathrm{x}}$ budget.

The box model photochemistry alone is unable to explain observed concentrations of $\mathrm{CH}_{2} \mathrm{O}$ or $\mathrm{H}_{2} \mathrm{O}_{2}$ during ARCTAS; observations are larger than box model predictions by factors of $\sim 2-3$ during spring and by 50-200\% during summer. Predictions of $\mathrm{HO}_{2}$ resulting from these combined lower model predicted precursor values are more consistent with observed $\mathrm{HO}_{2}$, further highlighting the inconsistency between the measurements of $\mathrm{HO}_{\mathrm{x}}$ and its precursors. Sensitivity simulations were also run where $\mathrm{CH}_{2} \mathrm{O}$ was predicted while keeping peroxides constrained to observations, and vice versa, with peroxides beeing predicted while using constraint of observed $\mathrm{CH}_{2} \mathrm{O}$. Photochemistry resulting from observed concentrations of peroxides is unable to reproduce observed values of $\mathrm{CH}_{2} \mathrm{O}$. However, when the model is constrained to observed $\mathrm{CH}_{2} \mathrm{O}$, predictions of $\mathrm{H}_{2} \mathrm{O}_{2}$ using a range of rainout loss rates bracket observations.

Observations of acetaldehyde are larger than model predictions, and can provide an additional photochemical source of $\mathrm{CH}_{2} \mathrm{O}$ that can explain up to half of the discrepancy between the model and measurements for portions of the troposphere. A source to explain larger acetaldehyde concentrations could be a result of oxidation of organic aerosols
Table A1. $1 \sigma$ uncertainties for selected input constraints on $60 \mathrm{~s}$ time average.

\begin{tabular}{|c|c|}
\hline Constraint & $1 \sigma$ uncertainty for $60 \mathrm{~s}$ average for ARCTAS \\
\hline $\mathrm{O}_{3}$ & $4.3 \%$ (for $\left.\mathrm{O}_{3}<=10 \mathrm{ppbv}\right) 4 \%$ (for $\mathrm{O}_{3}>10 \mathrm{ppbv}$ ) \\
\hline $\mathrm{CO}$ & $2 \%$ \\
\hline \multirow[t]{3}{*}{ NO } & 8 pptv (for NO $<100$ pptv) \\
\hline & 10 pptv (for NO $100-1000$ pptv) \\
\hline & 60 pptv (for NO $>1000$ pptv) \\
\hline \multirow[t]{2}{*}{$\mathrm{CH}_{3} \mathrm{OOH}$} & 33 pptv $+27 \%$ (for $\left.\mathrm{H}_{2} \mathrm{O} 0-230 \mathrm{ppmv}\right)$ \\
\hline & $\begin{array}{l}33 \text { pptv }+\left(-6.07+13.87 \log \left(\mathrm{H}_{2} \mathrm{O}\right)\right) \% \\
\left(\text { for } \mathrm{H}_{2} \mathrm{O}>230 \mathrm{ppmv}\right)\end{array}$ \\
\hline \multirow[t]{2}{*}{$\mathrm{H}_{2} \mathrm{O}_{2}$} & $67 \mathrm{pptv}+27 \%($ ARCTAS-A) \\
\hline & $67 \mathrm{pptv}+33 \%($ ARCTAS-B) \\
\hline $\mathrm{H}_{2} \mathrm{O}$ & Greater of $5 \%$ or $1 \mathrm{ppmv}$ \\
\hline $\mathrm{CH}_{2} \mathrm{O}$ & $\sqrt{\left(12.2 \%\left[\mathrm{CH}_{2} \mathrm{O}\right]\right)^{2}+\left(\mathrm{LOD}_{(\sim 22 \mathrm{ppt})}\right)^{2}}$ \\
\hline
\end{tabular}

and/or unmeasured NMHC species, but the origin of such a precursor(s) that is pervasive throughout the higher latitudes is unknown.

Gross $\mathrm{O}_{3}$ production during ARCTAS-A maximizes at $0.8 \mathrm{ppbv} \mathrm{d}^{-1}$ from $1-4 \mathrm{~km}$, which is generally consistent with estimates from TOPSE. The net photochemical tendency is zero throughout the troposphere, indicating that transport of $\mathrm{O}_{3}$ from middle latitudes is necessary to explain the springtime buildup of $\mathrm{O}_{3}$ over high latitudes. During ARCTAS-B, there is a gross photochemical $\mathrm{O}_{3}$ production of $2-4 \mathrm{ppbv} \mathrm{d}^{-1}$ in the boundary layer and at highest altitudes, with net photochemical tendencies of $<2 \mathrm{ppbv}$ day $^{-1}$, while the middle troposphere is a net photochemical sink for $\mathrm{O}_{3}$. The use of observed concentrations of $\mathrm{HO}_{2}$ rather than model predictions decreased the gross photochemical formation rates above the boundary layer by $25-50 \%$. However, because the gross destruction of $\mathrm{O}_{3}$ is reduced by a similar amount, the net photochemical production was relatively unaffected by the choice of modeled or measured $\mathrm{HO}_{2}$.

\section{Appendix A}

\section{Model uncertainty analysis}

Sources of uncertainty in model predictions include uncertainties in kinetic and photolytic rate constants, and uncertainties in measurements of constraining observations. One method of estimating the model uncertainty uses a Monte Carlo approach, which can be executed for typical meteorological and chemical conditions for a region(s) of interest. Median observed values are found for lower $(0-4 \mathrm{~km})$, middle $(4-8 \mathrm{~km})$ and upper $(>8 \mathrm{~km})$ altitudes during each of the two ARCTAS phases. For each of these six sets of median conditions, the model uncertainty due to kinetics was calculated by running 2500 simulations whereby each of 105 model kinetic reaction rates and 16 photolytic rates was randomly and independently varied within its referenced $1 \sigma$ 
Table A2. $2 \sigma$ Uncertainty in model predictions for ARCTAS-A (Fully Constrained Model).

\begin{tabular}{|c|c|c|c|c|}
\hline & $\begin{array}{l}\text { SENSITIVITY } \\
\text { APPROACH }\end{array}$ & $\begin{array}{l}\text { MONTE } \\
\text { CARLO } \\
\text { APPROACH }\end{array}$ & $\begin{array}{l}\text { MONTE } \\
\text { CARLO } \\
\text { APPROACH }\end{array}$ & $\begin{array}{l}\text { MONTE } \\
\text { CARLO } \\
\text { APPROACH }\end{array}$ \\
\hline Altitude & $\begin{array}{l}\text { Median } 2 \sigma \\
\mathrm{HO}_{2 \text { calc }} \\
\text { Obs. Constraint } \\
\text { (Relative) }\end{array}$ & $\begin{array}{l}2 \sigma \mathrm{HO}_{2 \text { calc }} \\
\text { Obs. Constraint } \\
\text { Relative (pptv) }\end{array}$ & $\begin{array}{l}2 \sigma \mathrm{HO}_{2 \text { calc }} \\
\text { Kinetics } \\
\text { Relative (pptv) }\end{array}$ & $\begin{array}{l}2 \sigma \mathrm{HO}_{2 \mathrm{calc}} \\
\text { Combined } \\
\text { Relative }\end{array}$ \\
\hline $\begin{array}{l}>8 \mathrm{~km} \\
4-8 \mathrm{~km} \\
0-4 \mathrm{~km}\end{array}$ & $\begin{array}{l}.24 \\
.22 \\
.20\end{array}$ & $\begin{array}{l}.25(2.13) \\
.21(1.72) \\
.14(0.88)\end{array}$ & $\begin{array}{l}.29(2.39) \\
.26(2.19) \\
.24(1.52)\end{array}$ & $\begin{array}{l}.38 \\
.33 \\
.28\end{array}$ \\
\hline Altitude & $\begin{array}{l}\text { Median } 2 \sigma \\
\text { OH }_{\text {calc }} \\
\text { Obs. Constraint } \\
\text { (Relative) }\end{array}$ & $\begin{array}{l}2 \sigma \mathrm{OH}_{\mathrm{calc}} \\
\text { Obs. Constraint } \\
\text { Relative (pptv) }\end{array}$ & $\begin{array}{l}2 \sigma \mathrm{OH}_{\text {calc }} \\
\text { Kinetics } \\
\text { Relative (pptv) }\end{array}$ & $\begin{array}{l}2 \sigma \mathrm{OH}_{\text {calc }} \\
\text { Combined } \\
\text { Relative }\end{array}$ \\
\hline $\begin{array}{l}>8 \mathrm{~km} \\
4-8 \mathrm{~km} \\
0-4 \mathrm{~km}\end{array}$ & $\begin{array}{l}.60 \\
.64 \\
.68\end{array}$ & $\begin{array}{l}.56(0.04) \\
.58(0.03) \\
.50(0.03)\end{array}$ & $\begin{array}{l}.41(0.03) \\
.36(0.02) \\
.31(0.01)\end{array}$ & $\begin{array}{l}.69 \\
.68 \\
.59\end{array}$ \\
\hline
\end{tabular}

Table A3. $2 \sigma$ Uncertainty in model predictions for ARCTAS-B (Fully constrained Model).

\begin{tabular}{|c|c|c|c|c|}
\hline & $\begin{array}{l}\text { SENSITIVITY } \\
\text { APPROACH }\end{array}$ & $\begin{array}{l}\text { MONTE } \\
\text { CARLO } \\
\text { APPROACH }\end{array}$ & $\begin{array}{l}\text { MONTE } \\
\text { CARLO } \\
\text { APPROACH }\end{array}$ & $\begin{array}{l}\text { MONTE } \\
\text { CARLO } \\
\text { APPROACH }\end{array}$ \\
\hline Altitude & $\begin{array}{l}\text { Median } 2 \sigma \\
\mathrm{HO}_{2 \text { calc }} \\
\text { Obs. Constraint } \\
\text { (Relative) }\end{array}$ & $\begin{array}{l}2 \sigma \mathrm{HO}_{2 \mathrm{calc}} \\
\text { Obs. Constraint } \\
\text { Relative (pptv) }\end{array}$ & $\begin{array}{l}2 \sigma \mathrm{HO}_{2 \text { calc }} \\
\text { Kinetics } \\
\text { Relative (pptv) }\end{array}$ & $\begin{array}{l}2 \sigma \mathrm{HO}_{2 \mathrm{calc}} \\
\text { Combined } \\
\text { Relative }\end{array}$ \\
\hline$>8 \mathrm{~km}$ & .16 & $.14(2.60)$ & $.28(5.01)$ & .31 \\
\hline $4-8 \mathrm{~km}$ & .14 & $.12(2.22)$ & .25 (4.56) & .28 \\
\hline $0-4 \mathrm{~km}$ & .08 & $.09(1.52)$ & $.23(4.02)$ & .25 \\
\hline Altitude & $\begin{array}{l}\text { Median } 2 \sigma \\
\text { OH }_{\text {calc }} \\
\text { Obs. Constraint } \\
\text { (Relative) }\end{array}$ & $\begin{array}{l}2 \sigma \mathrm{OH}_{\text {calc }} \\
\text { Obs. Constraint } \\
\text { Relative (pptv) }\end{array}$ & $\begin{array}{l}2 \sigma \mathrm{OH}_{\text {calc }} \\
\text { Kinetics } \\
\text { Relative (pptv) }\end{array}$ & $\begin{array}{l}2 \sigma \mathrm{OH}_{\text {calc }} \\
\text { Combined } \\
\text { Relative }\end{array}$ \\
\hline$>8 \mathrm{~km}$ & .34 & $.33(0.08)$ & $.35(0.08)$ & .48 \\
\hline $4-8 \mathrm{~km}$ & .44 & $.51(0.08)$ & $.33(0.05)$ & .61 \\
\hline $0-4 \mathrm{~km}$ & .32 & $.29(0.02)$ & $.33(0.03)$ & .44 \\
\hline
\end{tabular}

uncertainty (Sander et al., 2006; Atkinson et al., 2005). The resulting range in predictions of radical species was used to find the model predictive uncertainty (converted to $2 \sigma$ ) due to kinetic uncertainties.

To evaluate uncertainty due to constraining species, another set of Monte Carlo simulations was performed for the six sets of median input conditions, whereby each of seven selected constraining species was randomly and independently varied within the $1 \sigma$ measurement uncertainty for a $60 \mathrm{~s}$ average (Table A1). The resulting $2 \sigma$ uncertainties in model predictions of $\mathrm{OH}, \mathrm{HO}_{2}$ are shown in Tables $\mathrm{A} 2$ and A3 for ARCTAS-A and ARCTAS-B. A total model uncer- tainty is estimated using a quadrature sum of these two components.

Because these uncertainty estimates are based on a limited set of input conditions, they should be interpreted as representative of a general bulk analysis of the data. Uncertainties for the individual data points will vary, depending upon the meteorology and chemical regime (i.e., dominant reactions). Rigorous calculation of uncertainties for each individual data point using the Monte Carlo approach would require an exorbitant amount of computing time. To estimate the predictive uncertainty for an individual data point, a "Sensitivity" approach may be employed, whereby each data point is run $N$ times $\left(N=N_{\text {con }}+N_{\text {kin }}\right)$, where $N_{\text {con }}$ is the number of 

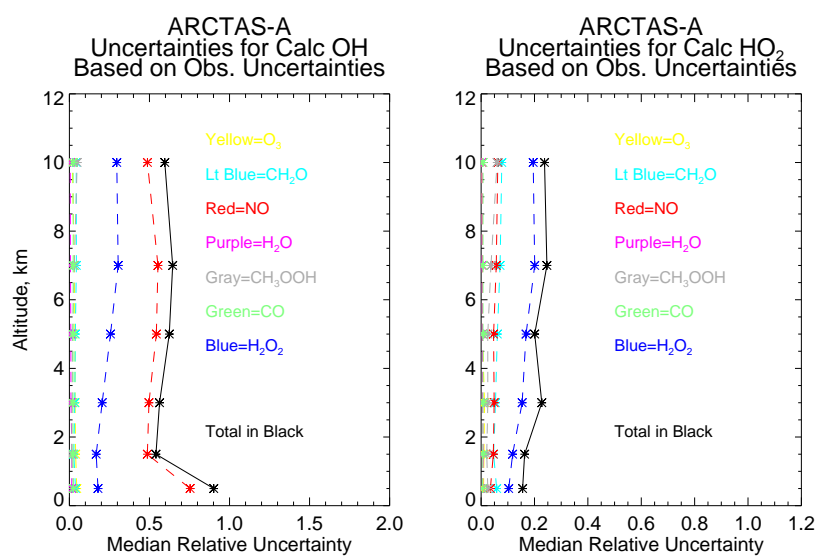

Fig. A1. Altitude profiles of the median relative uncertainty in prediction of (a) $\mathrm{OH}$ and of (b) $\mathrm{HO}_{2}$ during ARCTAS-A that is due to the uncertainty in observations of constraining species.
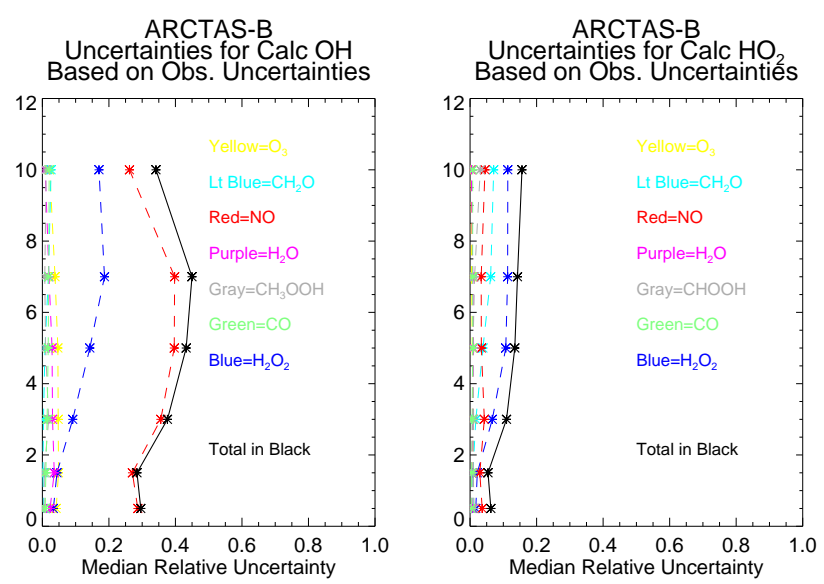

Fig. A2. As for Fig. A1, but for ARCTAS-B.

observational constraints selected to consider, and $N_{\text {kin }}$ is the number of kinetic reactions selected to consider. For these sensitivity simulations, the component of interest (an observational constraint or a reaction rate) is increased by its $1 \sigma$ uncertainty, and the absolute value of the relative difference in radical predictions is calculated. A quadrature sum of uncertainties obtained from each considered component gives an estimate of the total combined uncertainty for that individual data point. For comparison to the Monte Carlo results, Tables A2 and A3 also show the medians of the combined uncertainties obtained using the sensitivity approach for the 7 constraints listed in Table A1.

Figures A1 (ARCTAS-A) and A2 (ARCTAS-B) show the individual contributions to the observational constraint uncertainty for prediction of $\mathrm{OH}$ and $\mathrm{HO}_{2}$ from seven selected measurements. The dominant measurement uncertainty impacting $\mathrm{OH}$ prediction is clearly $\mathrm{NO}$, while $\mathrm{H}_{2} \mathrm{O}_{2}$ dominates the uncertainty in prediction of $\mathrm{HO}_{2}$.
Acknowledgements. The ARCTAS mission was funded by the NASA Global Tropospheric Chemistry Program, the NASA Radiation Sciences Program, and the California Air Resources Board. We gratefully acknowledge the NASA aircraft crews and science team. The two anonymous reviewers for this manuscript are also thanked.

Edited by: W. T. Sturges

\section{References}

Apel, E. C, Hills, A. J., Lueb, R., Zindel, S. , Eisele, S., and Riemer, D. D.: A fast-GC/MS system to measure $C_{2}$ to $C_{4}$ carbonyls and methanol aboard aircraft, J. Geophys. Res., 108, 8794, doi:10.1029/2002JD003199, 2003.

Apel, E. C., Olson, J. R., Crawford, J. H., Hornbrook, R. S., Hills, A. J., Cantrell, C. A., Emmons, L. K., Knapp, D. J., Hall, S., Mauldin III, R. L., Weinheimer, A. J., Fried, A., Blake, D. R., Crounse, J. D., Clair, J. M. St., Wennberg, P. O., Diskin, G. S., Fuelberg, H. E., Wisthaler, A., Mikoviny, T., Brune, W., and Riemer, D. D.: Impact of the deep convection of isoprene and other reactive trace species on radicals and ozone in the upper troposphere, Atmos. Chem. Phys., 12, 1135-1150, doi:10.5194/acp-12-1135-2012, 2012.

Atkinson, R., Baulch, D. L., Cox, R. A., Crowley, J. N., Hampson, R. F., Hynes, R. G., Jenkin, M. E., Rossi, M. J., Troe, J., and IUPAC Subcommittee: Evaluated kinetic and photochemical data for atmospheric chemistry: Volume II - gas phase reactions of organic species, Atmos. Chem. Phys., 6, 3625-4055, doi:10.5194/acp-6-3625-2006, 2006.

Atlas, E. L., Ridley, B. A., and Cantrell, C. A.: The tropospheric ozone production about the Spring Equinox (TOPSE) Experiment: Introduction, J. Geophys. Res., 108, 8353, doi:10.1029/2002JD003172, 2003.

Barrie, L. A., Bottenhein, J. W., Schnell, R. C., Crutzen, P. J., and Rasmussen, R. A.: Ozone destruction and photochemical reactions at polar sunrise in the lower Arctic atmosphere, Nature, 334, 138-141, 1988.

Blake, N. J., Blake, D. R., Swanson, A. L., Atlas, E., Flocke F., and Rowland, F. S.: Latitudinal, vertical and seasonal variations in C1-C4 alkyl nitrates in the troposphere over the Pacific Ocean during PEM-Tropics A and B: Oceanic and continental sources, J. Geophys. Res., 108, 8806, doi:10.1029/2002JD003367, 2003.

Bloss, W. J., Lee, J. D., Johnson, G. P., Sommariva, R., Heard, D. E., Saiz-Lopez, A., Plane, J. M. C., McFiggans, G., Coe, H., Flynn, M., Williams, P., Rickard, A. R., and Fleming, Z. L.: Impact of halogen monoxide chemistry upon boundary layer $\mathrm{OH}$ and $\mathrm{HO} 2$ concentrations at a coastel site, Geophys. Res. Lett., 32, L06814, doi:10.1029/2004GL022084, 2005.

Brock, C. A., Radke, L. F., Lyons, J. H., and Hobbs, P. V.: Arctic hazes in summer over Greenland and the North American Arctic. I: Incidence and origins, J. Atmos. Chem., 9, 129-148, doi:10.1007/BF00052828, 1989.

Browne, E. C., Perring, A. E., Wooldridge, P. J., Apel, E., Hall, S. R., Huey, L. G., Mao, J., Spencer, K. M., Clair, J. M. St., Weinheimer, A. J., Wisthaler, A., and Cohen, R. C.: Global and regional effects of the photochemistry of $\mathrm{CH}_{3} \mathrm{O}_{2} \mathrm{NO}_{2}$ : evidence from ARCTAS, Atmos. Chem. Phys., 11, 4209-4219, doi:10.5194/acp-11-4209-2011, 2011. 
Brune, W. H., Tan, D., Faloona, I. F., Jaeglé, L., Jacob, D. J., Heikes, B. G., Snow, J., Kondo, Y., Shetter, R., Sachse, G. W., Anderson, B., Gregory, G. L., Vay, S., Singh, H. B., Davis, D. D., Crawford, J. H., and Blake, D. R.: $\mathrm{OH}$ and $\mathrm{HO}_{2}$ chemistry in the North Atlantic free Troposphere, Geophys. Res. Lett., 26, 3077-3080, 1999.

Cantrell, C. A. Mauldin, L., Zondlo, M., Eisele, F., Kosciuch, E., Shetter, R., Lefer, B., Hall, S., Campos, R., Ridley, B., Walega, J., Fried, A., Wert, B., flocke, F., Weinheimer, A., Hannigan, J., Coffey, M., Atlas, E., Stephens, S., Heikes, B., Snow, J., Blake, D., Blake, N., Katzenstein, A., Lopez, J. Browell, E. V., Dibb, J., Scheuer, E., Seid, G., and Talbot, R.: Steady state free radical budgets and ozone photochemistry during TOPSE, J. Geophys. Res., 108, 8361, doi:10.1029/2002JD002198, 2003a.

Cantrell, C. A., Edwards, G. D., Stephens, S., Mauldin, R. L., Zondlo, M. A., Kosciuch, E., Eisele, F. L., Shetter, R. E., Lefer, B. L., Hall, S., Flocke, F., Weinheimer, A., Fried, A., Apel, E., Kondo, Y., Blake, D. R., Blake, N. J., Simpson, I. U. J., Bandy, A. R., Thornton, D. C., Heikes, B. G., Singh, H. B., Brune, W. H., Harder, H., Martinez, M., Jacob, D. J., Avery, M. A., Barrick, J. D., Sachse, G. W., Olson, J. R., Crawford, J. H., and Clarke, A. D.: Peroxy radical behavior during the Transport and Chemical Evolution over the Pacific (TRACE-P) campaign as measured aboard the NASA P-3B aircraft, J. Geophys. Res., 108, 8797, doi:10.1029/2003JD003674, 2003b.

Carr, S., Heard, D. E., and Blitz, M. A.: Comment on "Atmospheric Hydroxyl Radical Production from Electronically Excited $\mathrm{NO}_{2}$ and $\mathrm{H}_{2} \mathrm{O}$ ", Science, 324, 336, doi:10.1126/science.1166669, 2009.

Chen, G., Davis, D., Crawford, J., Hutterli, L. M., Huey, L. G., Slusher, D., Mauldin, L., Eisele, F., Tanner, D., Dibb, J., Buhr, M., McConnell, J., Lefer, B., Shetter, R., Blake, D., Song, C. H., Lombardi, K., and Arnoldy, J.: A reassessment of $\mathrm{HO}_{\mathrm{x}}$ South Pole chemistry based on observations recorded during ISCAT 2000, Atmos. Environ., 38, 5451-5461, 2004.

Clark, A. D.: A Thermo-optic technique for in-situ analysis of sizeresolved aerosol Physicochemistry, Atmos. Environ., 25A, 635644, 1991

Comiso, J. C., Parkinson, C. L., Gersten, R., and Stock, L.: Accelerated decline in the Arctic sea ice cover, Geophys. Res. Lett., 35, L01703, doi:10.1029/2007GL031972, 2008.

Crawford, J., Davis, D., Olson, J., Chen, G., Liu, S., Gregory, G., Barrick, J., Sachse, G., Sandholm, S., Heikes, B., Singh, H., and Blake, D.: Assessment of upper tropospheric $\mathrm{HO}_{\mathrm{x}}$ sources over the tropical Pacific based on NASA GTE/PEM data: Net effect on $\mathrm{HO}_{\mathrm{x}}$ and other photochemical parameters, J. Geophys. Res., 104, 16255-16273, 1999.

Crounse, J. D., McKinney, K. A., Kwan, A. J., and Wennberg, P. O.: Measurement of gas-phase hydroperoxides by chemical ionization mass spectrometry, Anal. Chem., 78, 6726-6732, 2006.

Diskin, G. S.: Open-path Airborne Tunable Diode Laser Hydrometer, Diode Lasers and Applications in Atmospheric Sensing, SPIE Proceedings 4817, A. Fried, editor, 196-204, 2002.

Elrod, M. J., Ranschaert, D. L., and Schneider, N. L.: Direct kinetic study of the temperature dependence of the $\mathrm{CH}_{2} \mathrm{O}$ branching channel for the $\mathrm{CH}_{3} \mathrm{O}_{2}+\mathrm{HO}_{2}$ reaction, Int. J. Chem. Kinet., 33, 363-376, 2001.

Emmons, L.K., Hess, P., Klonecki, A., Tie, X., Horowitz, L., Lamarque, J.-F., Kinnison, D., Brasseur, G., Atlas, E., Brow- ell, E., Cantrell, C., Eisele, F., Mauldin, R.L., Merrill, J., Ridley, B., and Shetter, R.: Budget of tropospheric ozone during TOPSE from two Chemical transport models, J. Geophys. Res., 108, 8372, doi:10.1029/2002JD002665, 2003.

Evans, M. J., Jacob, D. J., Atlas, E., Cantrell, C. A., Eisele, F., Flocke, F., Fried, A., Mauldin, R. L., Ridley, B. A., Wert, B., Talbot, R., Blake, D., Heikes, B., Snow, J., Walega, J. Weinheimer, A. J., and Dibb, J.: Coupled evolution of $\mathrm{BrO}_{\mathrm{x}}-\mathrm{ClO}_{\mathrm{x}}-$ $\mathrm{HO}_{\mathrm{x}}-\mathrm{NO}_{\mathrm{x}}$ chemistry during bromine-catalyzed ozone depletion events in the arctic boundary layer, J. Geophys. Res., 108, 8368, doi:10.1029/2002JD002732, 2003.

Faloona, I., Tan, D., Lesher, R. L., Hazen, N. L., Frame, C. L., Simpas, J. B., Harder, H., Martinez, M., DiCarlo, P., Ren, X., and Brune, W. H.: A Laser-induced Fluorescence Instrument for Detecting Tropospheric $\mathrm{OH}$ and $\mathrm{HO}_{2}$ : Characteristics and Calibration, J. Atmos. Chem., 47, 139-167, 2004.

Fisher, J. A., Jacob, D. J., Purdy, M. T., Kopacz, M., Le Sager, P., Carouge, C., Holmes, C. D., Yantosca, R. M., Batchelor, R. L., Strong, K., Diskin, G. S., Fuelberg, H. E., Holloway, J. S., Hyer, E. J., McMillan, W. W., Warner, J., Streets, D. G., Zhang, Q., Wang, Y., and Wu, S.: Source attribution and interannual variability of Arctic pollution in spring constrained by aircraft (ARCTAS, ARCPAC) and satellite (AIRS) observations of carbon monoxide, Atmos. Chem. Phys., 10, 977-996, doi:10.5194/acp10-977-2010, 2010.

Frey, M. M., Hutterli, M. A., Chen, G., Sjostedt, S. J., Burkhart, J. F., Friel, D. K., and Bales, R. C.: Contrasting atmospheric boundary layer chemistry of methylhydroperoxide $\left(\mathrm{CH}_{3} \mathrm{OOH}\right)$ and hydrogen peroxide $\left(\mathrm{H}_{2} \mathrm{O}_{2}\right)$ above polar snow, Atmos. Chem. Phys., 9, 3261-3276, doi:10.5194/acp-9-3261-2009, 2009.

Fried, A., Wang, Y., Cantrell, C., Wert, B., Walega, J., Ridley, B., Atlas, E., Shetter, R., Lefer, B., Coffey, M. T., Hannigan, J., Blake, D., Blake, N., Meinardi, s., Talbot, B., Dibb, J., Scheuer, E., Wingenter, O., Snow, J., Heikes, B., and Ehhalt, D.: Tunable diode laser measurements of formaldehyde during the TOPSE 2000 study: Distributions, trends, and model comparisons, J. Geophys. Res., 108 8365, doi:10.1029/2002JD002208, 2003.

Fuchs, H., Bohn, B., Hofzumahaus, A., Holland, F., Lu, K. D., Nehr, S., Rohrer, F., and Wahner, A.: Detection of $\mathrm{HO}_{2}$ by laserinduced fluorescence: calibration and interferences from $\mathrm{RO}_{2}$ radicals, Atmos. Meas. Tech., 4, 1209-1225, doi:10.5194/amt4-1209-2011, 2011.

Fuelberg, H. E., Harrigan, D. L., and Sessions, W.: A meteorological overview of the ARCTAS 2008 mission, Atmos. Chem. Phys., 10, 817-842, doi:10.5194/acp-10-817-2010, 2010.

Jacob, D. J., Crawford, J. H., Maring, H., Clarke, A. D., Dibb, J. E., Emmons, L. K., Ferrare, R. A., Hostetler, C. A., Russell, P. B., Singh, H. B., Thompson, A. M., Shaw, G. E., McCauley, E., Pederson, J. R., and Fisher, J. A.: The Arctic Research of the Composition of the Troposphere from Aircraft and Satellites (ARCTAS) mission: design, execution, and first results, Atmos. Chem. Phys., 10, 5191-5212, doi:10.5194/acp-10-5191-2010, 2010.

Kwan, A. J., Crounse, J. D., Clarke, A., Shinozuka, Y., Anderson, B. E., Crawford, J. H., Avery, M. A., McNaughton, C., Brune, W. H., Singh, H. B., and Wennberg, P. O.: On the flux of oxygenated volatile organic compounds from organic aerosol oxidation, Geophys. Res. Lett., 33, L15815, doi:10.1029/2006GL026144, 2006.

Law, K. S. and Stohl: A. Arctic air pollution: origins and impacts, Science, 315,1537-1540, doi:10.1126/science.1137695, 2007. 
Lee, M., D. O'Sullivan, Noone, K. B., and Heikes, B. G.: HPLC method for determination of $\mathrm{H}_{2} \mathrm{O}_{2}, \mathrm{C}_{1}$ and $\mathrm{C}_{2}$ hydroperoxides in the atmosphere, J. Atmos. Oceanic Technol., 12, 1060-1070, 1995.

Lemke, P., Ren, J., Alley, R. B., Allison, I., Carrasco, J., Flato, G., Fujii, Y., Kaser, G., Mote, P., Thomas, R. H., and Zhang, T.: Observations: Changes in Snow, Ice and Frozen Ground, Climate Change 2007: The Physical Science Basis. Contribution of Working Group I to the Fourth Assessment Report of the Intergovernmental Panel on Climate Change, edited by: Solomon, S., Qin, D., Manning, M., Chen, Z., Marquis, M., Averyt, K. B., Tignor, M., and Miller, H. L., Cambridge University Press, Cambridge, United Kingdom and New York, NY, USA, 2007.

Li, S., Matthews, J., and Sinha, A.: Atmospheric Hydroxyl Radical Production from Electronically Excited $\mathrm{NO}_{2}$ and $\mathrm{H}_{2} \mathrm{O}$, Science, 319, 1657-1660, 2008.

Liao, J., Huey, L. G., Tanner, D. J., Brough, N., Brooks, S., Dibb, J. E., Stutz, J., Thomas, J. L., Lefer, B., Haman, C., and Gorham, K.: Observations of hydroxyl and peroxy radicals and the impact of BrO at Summit, Greenland in 2007 and 2008, Atmos. Chem. Phys., 11, 8577-8591, doi:10.5194/acp-11-8577-2011, 2011.

Logan, J. A., Prather, M. J., Wofsy, S. C., and McElroy, M. B.: Tropospheric chemistry: A global perspective, J. Geophys. Res., 86, 7210-7254, 1981.

Lurmann, F. W., Lloyd, A. C., and Atkinson, R.: A chemical mechanism for use in long-range transport/acid deposition computer modeling, J. Geophys. Res., 91, 10905-10936, 1986.

Madronich, S. and Flocke, S.: The role of solar radiation in atmospheric chemistry, in: Handbook of Environmental Chemistry, edited by: Boule, P., 1-26, Springer, New York, 1998.

Mahajan, A. S., Shaw, M., Oetjen, H., Hornsby, K. E., Carpenter, L. J., Kaleschke, L., Tian-Kunze, X., Lee, J. D., Moller, S. J., Edwards, P., Commane, R., Ingham, T., Heard, D. E., and Plane, J. M.: Evidence of reactive iodine chemistry in the Arctic boundary layer, J. Geophys. Red., 115, D20303, doi:10.1029/2009JD013665, 2010.

Mao, J., Jacob, D. J., Evans, M. J., Olson, J. R., Ren, X., Brune, W. H., Clair, J. M. St., Crounse, J. D., Spencer, K. M., Beaver, M. R., Wennberg, P. O., Cubison, M. J., Jimenez, J. L., Fried, A., Weibring, P., Walega, J. G., Hall, S. R., Weinheimer, A. J., Cohen, R. C., Chen, G., Crawford, J. H., McNaughton, C., Clarke, A. D., Jaeglé, L., Fisher, J. A., Yantosca, R. M., Le Sager, P., and Carouge, C.: Chemistry of hydrogen oxide radicals $\left(\mathrm{HO}_{\mathrm{x}}\right)$ in the Arctic troposphere in spring, Atmos. Chem. Phys., 10, 58235838, doi:10.5194/acp-10-5823-2010, 2010.

Mao, J., Ren, X., Brune, W. H., Van Duin, D. M., Cohen, R. C., Park, J.-H., Goldstein, A. H., Paulot, F., Beaver, M. R., Crounse, J. D., Wennberg, P. O., DiGangi, J. P., Henry, S. B., Keutsch, F. N., Park, C., Schade, G. W., Wolfe, G. M., and Thornton, J. A.: Insights into hydroxyl measurements and atmospheric oxidation in a California forest, Atmos. Chem. Phys. Discuss., 12, 67156744, doi:10.5194/acpd-12-6715-2012, 2012.

Mauldin III, R. L., Tanner, D. J., and Eisele, F. L.: Measurements of OH during PEM-Tropics A, J. Geophys. Res., 104, 5817-5827, 1999.

McElroy, C. T., McLinden, C. A., and McConnell, J. C.: Evidence for bromine monoxide in the free troposphere during the Arctic polar sunrise, Nature, 397, 338-341, doi:10.1038/16904, 1999.
Neuman, J. A., Nowak, J. B., Huey, L. G., Burkholder, J. B., Dibb, J. E., Holloway, J. S., Liao, J., Peischl, J., Roberts, J. M., Ryerson, T. B., Scheuer, E., Stark, H., Stickel, R. E., Tanner, D. J., and Weinheimer, A.: Bromine measurements in ozone depleted air over the Arctic Ocean, Atmos. Chem. Phys., 10, 6503-6514, doi:10.5194/acp-10-6503-2010, 2010.

Olson, J. R., Crawford, J. H., Chen, G., Brune, W. H., Faloona, I. C., Tan, D., Harder, H., and Martinez, M.: A reevaluation of airborne $\mathrm{HO}_{\mathrm{x}}$ observations from NASA field campaigns, J. Geophys Res., 111 D10301, doi:10.1029/2005JD006617, 2006.

Oltmans, S. J.: Surface ozone measurements in clean air, J. Geophys. Res., 86, 1174-1180, 1981.

Oltmans, S. J. and Komhyr, W.: Surface ozone distributions and variations from 1973-1984: measurements at the NOAA geophysical monitoring for climatic change baseline observatories, J. Geophys. Res., 91, 5229-5236, doi:10.1029/JD091iD04p05229, 1986.

Orlando, J. J. and Tyndall, G. S.: Rate coefficients for the thermal decomposition of $\mathrm{BrONO}_{2}$ and the heat of formation of BrONO $_{2}$, J. Phys. Chem., 100, 19298-19405, 1996.

Quinn, P. K., Bates, T. S., Baum, E., Doubleday, N., Fiore, A. M., Flanner, M., Fridlind, A., Garrett, T. J., Koch, D., Menon, S., Shindell, D., Stohl, A., and Warren, S. G.: Short-lived pollutants in the Arctic: their climate impact and possible mitigation strategies, Atmos. Chem. Phys., 8, 1723-1735, doi:10.5194/acp8-1723-2008, 2008.

Radke, L. , Hobbs, P., and Bailey, I.: Airborne observations of Arctic aerosols. III: Origins and effects of airmasses, Geophys. Res. Lett., 11, 401-404, doi:10.1029/GL011i005p00401, 1984.

Ren, X., Mao, J., Brune, W. H., Cantrell, C. A., Mauldin III, R. L., Hornbrook, R. S., Kosciuch, E., Olson, J. R., Crawford, J. H., Chen, G., and Singh, H. B.: Airborne intercomparison of $\mathrm{HO}_{\mathrm{x}}$ measurements using laser-induced fluorescence and chemical ionization mass spectrometry during ARCTAS, Atmos. Meas. Tech. Discuss., 5, 2529-2565, doi:10.5194/amtd-5-2529-2012, 2012.

Rinsland, C. P., Coheur, P. F., Herbin, H., Clerbaux, C., Boone, C., Bernath, P., and Chiou, L. S.: Detection of elevated tropospheric hydrogen peroxide $\left(\mathrm{H}_{2} \mathrm{O}_{2}\right)$ mixing ratios in atmospheric chemistry experiment (ACE) subtropical infrared solar occultation spectra, J. Quant. Spectrosc. Ra., 107, 340-348, 2007.

Sachse, G., Hill, G., Wade, L., and Perry, M.: Fast-response, highprecision carbon monoxide sensor using a tunable diode laser absorption technique, J. Geophys. Res., 92, 2095-2081, 2008.

Saiz-Lopez, A., Plane, J. M. C., Baker, A., Carpenter, L. J., vonGlasow, R., Gomez Martin, J. C., McFiggans, G., and Saunders, R. W.: Atmospheric Chemistry of Iodine, Chem. Rev., 112, 1773-1804, doi:10.1021/cr200029u, 2011.

Sander, S. P., Fridl, R. R., Ravishankara, A. R, Golden, D. M., Kolb, C. E., Kurylo, M. J., Molina, M. J., Moortgat, G. K., FinlaysonPitts, B. J., Wine, P. H., Huie, R. E., and Orkin, V. L.: Chemical kinetics and photochemical data for use in atmospheric studies, Evaluation Number 15, JPL Publ., 06-2, 2006.

Scheuer, E., Talbot, R. W., Dibb, J. E., Seid, G. K., deBell, L., and Lefer, G.: Seasonal distributions of fine aerosol sulfate in the North American Arctic Basin during TOPSE, J. Geophys. Res., 108, 8370, doi:10.1029/2001JD001364, 2003.

Shaw, G. E.: The Arctic phase phenomenon, B. Am . Meterol. Soc., 76, 2403-2413, 1995. 
Shetter, R. E. and Muller, M.: Photolysis frequency measurements using actinic flux spectroradiometry during the PEM-Tropics mission: Instrumentation description and some results, J. Geophys. Res., 104, 5647-5661, 1999.

Shindell, D. T., Faluvegi, G., Bauer, S. E., Koch, D. M., Unger, N., Menon, S., Miller, R. L., Schmidt, G. A., and Streets, D. G.: Climate response to projected changes in short-lived species under an A1B scenario from 200-2050 in the GISS climate model, J. Geophys Res., 112, D20103, doi:10.1029/2007JD008753, 2007.

Shindell, D. T., Chin, M., Dentener, F., Doherty, R. M., Faluvegi, G., Fiore, A. M., Hess, P., Koch, D. M., MacKenzie, I. A., Sanderson, M. G., Schultz, M. G., Schulz, M., Stevenson, D. S., Teich, H., Textor, C., Wild, O., Bergmann, D. J., Bey, I., Bian, H., Cuvelier, C., Duncan, B. N., Folberth, G., Horowitz, L. W., Jonson, J., Kaminski, J. W., Marmer, E., Park, R., Pringle, K. J., Schroeder, S., Szopa, S., Takemura, T., Zeng, G., Keating, T. J., and Zuber, A.: A multi-model assessment of pollution transport to the Arctic, Atmos. Chem. Phys., 8, 5353-5372, doi:10.5194/acp-85353-2008, 2008.

Singh, H. B., Brune, W. H., Crawford, J. H., Jacob, D. J., and Russell, P. B.: Overview of the summer 2004 Intercontinental Chemical Transport Experiment - North America (INTEX-A), J. Geophys. Res., 111, D24S01, doi:10.1029/2006JD007905, 2006.

Singh, H. B., Anderson, B. E., Brune, W. H., Cai, C., Cohen, R. C., Crawford, J. H., Cubison, M. J., Czech, E. P., Emmons, L., Fuelberg, H. E., Huey, G., Jacob, D. J., Jimenez, J. L., Kaduwela, A., Kondo, Y., Mao, J., Olson, J. R., Sachse, G. W., Vay, S. A., Weinheimer, A., Wennberg, P. O., Wisthaler, A., and the ARCTAS Science Team: Pollution influences on atmospheric composition and chemistry at high northern latitudes: Boreal and California forest fire emissions, Atmos. Environ., 44, 4553-4564, doi:10.1016/j.atmosenv.2010.08.026, 2010.

Slusher, D. L., Huey, L. G., Tanner, D. J., Flocke, F. M., and Roberts, J. M.: A thermal dissociation-chemical ionization mass spectrometry (td-cims) technique for the simultaneous measurement of peroxyacyl nitrates and dinitrogen pentoxide, J. Geophys. Res., 109, D19315, doi:10.1029/2004JD004670, 2004.

Snow, J. A., Heikes, B. G., Merrill, J. T., Wimmers, A. J., Moody, J. L., and Cantrell, C. A.: Winter-spring evolution and variability of HOx reservoir species, hydrogen peroxide, and methyl hydroperoxide in the northern middle to high latitudes, J. Geophys. Res., 108, 8362, doi:10.1029/2002JD002172, 2003.
Snow, J. A., Heikes, B. G., Shen, H., O'Sullivan, D. W., Fried, A., and Walega, J.: Hydrogen peroxide, methyl hydroperoxide, and formaldehyde over North America and the North Atlantic, J. Geophys. Res., 112, D12S07, doi:10.1029/2006JD007746, 2007.

Soller, R., Nicovich, J., and Wine, P.: Temperature-dependent rate coefficients for the reactions of $\operatorname{Br}\left({ }^{2} \mathrm{P}_{3 / 2}\right), \mathrm{Cl}\left({ }^{2} \mathrm{P}_{3 / 2}\right)$, and $\mathrm{O}\left({ }^{3} \mathrm{P}\right)$ with $\mathrm{BrONO}_{2}$, J. Phys. Chem. A., 105, 1416-1422, 2001.

Stohl, A.: Characteristics of atmospheric transport into the Arctic troposphere, J. Geophys. Res., 111, D11306, doi:10.1029/2005JD006888, 2006.

Stroud, C., Madronich, S., Atlas, E., Cantrell, C., Fried, A., Wert, B., Ridley, B., Eisele, F., Mauldin, L., Shetter, R., Lefer, B., Flocke, F., Weinheimer, A., Coffey, M., Heikes, B., Talbot, R., and Blake, C.: Photochemistry in the Arctic free troposphere: Ozone budget and its dependence on nitrogen oxides and the production rate of free radicals, J. Atmos. Chem., 47, 107-138, 2004.

Thornton, J. A., Jaeglé, L., and McNeill, V. F.: Assessing known pathways for $\mathrm{HO}_{2}$ loss in aqueous atmospheric aerosols: Regional and global impacts on tropospheric oxidants, J. Geophys. Res., 113, D05303, doi:10.1029/2007jd009236, 2008.

von Glasow, R., von Kuhlmann, R., Lawrence, M. G., Platt, U., and Crutzen, P. J.: Impact of reactive bromine chemistry in the troposphere, Atmos. Chem. Phys., 4, 2481-2497, doi:10.5194/acp-42481-2004, 2004.

Weibring, P., Richter, D., Walega, J. G., and Fried, A.: First demonstration of a high performance difference frequency spectrometer on airborne platforms, Optics Express, 15, 13476-13495, 2007.

Weinheimer, A. J., Walega, J. G., Ridley, B. A., Gary, G. L., Blake, D. R., Blake, N. J., Rowland, F. S., Sachse, G. W., Anderson, B. E., and Collins, J. E.: Meridional distributions of $\mathrm{NO}_{\mathrm{x}}, \mathrm{NO}_{\mathrm{y}}$ and other species in the lower stratosphere and upper troposphere during AASE II, Geophys. Res. Lett., 21, 2583-2586, 1994.

Wisthaler, A., Hansel, A., Dickerson, R. R., and Crutzen, P. J.: Organic trace gas measurements by PTR-MS during INDOEX 1999, J. Geophys. Res., 107, 8024, doi:10.1029/2001JD000576, 2002. 